\title{
SOBRE A EVOLUÇÃO TECTÔNICA DO ORÓGENO ARAÇUAÍ-CONGO OCIDENTAL
}

\author{
Fernando Flecha Alkmim¹, Antônio Carlos Pedrosa-Soares², \\ Carlos Maurício Noce ${ }^{2}$, Simone Cerqueira Pereira Cruz ${ }^{3}$
}

\begin{abstract}
The Araçuaí Belt, portrayed by Almeida (1977) as a brasiliano orogenic domain developed along the southeastern margin of the São Francisco Craton, is now viewed as part of the external zone of the so called Araçuaí-West Congo Orogen. This orogen, which also encompasses the West Congo Belt of Africa and the terrain between the Araçuaí Belt and the Brazilian continental margin, exhibits a whole series of puzzling features. Confined to a tongue-shaped enclave between the São Francisco and Congo cratons, the Araçuaí-West Congo Orogen involves, besides Neoproterozoic ophiolites, a large volume of plutonic rocks including subduction-related granites. Its evolution is thus associated with ocean floor spreading and subduction, processes difficult to reconcile with its confined nature. From a tectonic perspective, the AraçuaíWest Congo Orogen can be subdivided in ten compartments, which played distinct rules in the course of its development. Considering the peculiar setting it formed and knowing the kinematic function of the main structures, the tectonic evolution of the Araçuaí-West Congo Orogen can be best explain by a model that involves the closure of a basin partially floored by oceanic crust - the Macaúbas basin, iniciated around $880 \mathrm{Ma}$ - through a mechanism that resembles the operation of a nutcracker. The São Francisco and Congo cratons, like pincers of a nutcracker, and articulated along interior rifts (the Pirapora, Paramirim and Sangha aulacogens), rotated against each other, compressing the Macaúbas basin that lay in-between. The driven forces for the closure are probably triggered by collisions along the margins of the São Francisco-Congo plate during the final assembly of West Gondwana. The main collisional stage around $580 \mathrm{Ma}$ was followed by the lateral escape of the southern portion of the orogen and gravity collapse. We anticipate that the continuation of the study of the Brazilian or Araçuaí portion of the Araçuaí-West Congo Orogen, which correspond to an extraordinary natural lab, will bring solution not only for the enigmas presented by this peculiar orogen, but also for questions related to the anatomy and development of mountain belts in general.
\end{abstract}

Keywords: Araçuaí belt, Araçuai-West Congo orogen, Brasiliano-Pan African event, Neoproterozoic,, West Gondwana

\section{RESUMO}

Caracterizada, há 30 anos atrás, como cinturão de dobramentos brasilianos que limitaria o Cráton do São Francisco pelo sudeste e sul, a Faixa Araçuaí é hoje entendida como parte do domínio metamórfico externo do Orógeno Araçuaí-Congo Ocidental. Este componente da grande rede orogênica do Gondwana Ocidental que, na África, compreende a Faixa Oeste-Congolesa e, no Brasil, a Faixa Araçuaí e terrenos adjacentes a leste, possui uma série de atributos singulares. Contornado pelo Cráton do São Francisco-Congo e contíguo, a sul, ao sistema orogênico Ribeira exibe, em mapa, uma forma em ferradura e vergências centrífugas, o que a princípio sugere uma evolução essencialmente ensiálica. Os estudos realizados no Orógeno Araçuaí mostram, entretanto, que geração e consumo de assoalho oceânico constituem fases da sua evolução, como também o são vários pulsos de volumosa produção de magmas graníticos a partir de fontes tanto mantélicas, quanto crustais. Analisado do ponto de vista tectônico, o Orógeno Araçuaí-Congo Ociental pode ser subdividido em dez compartimentos, os quais desempenharam papéis distintos no curso de sua história. Dada a sua natureza confinada e as funções cinemáticas desempenhadas pelas peças do seu arcabouço, postulou-se a hipótese, ora em fase de teste, de que o Orogeno Araçuaí-Congo Ocidental tenha evoluído a partir de uma bacia parcialmente assoalhada por crosta oceânica - a Bacia Macaúbas, iniciada por volta de $880 \mathrm{Ma}$ - através um mecanismo que lembra a operação de um quebra-nozes. Ou seja, as peças cratônicas do São Francisco e do Congo, articuladas por meio de riftes interiores, mover-se-iam em sentidos opostos por forças de colisões em suas margens e promoveriam o fechamento da bacia mediterrânea precursora. Ao evento colisional principal, que se desencadeou por volta de $580 \mathrm{Ma}$, sucederam as fases de escape lateral da porção sul e de colapso gravitacional. Antevê-se que a continuidade do estudo da porção brasileira desta feição orogênica, que constitui um excepcional laboratório natural, trará respostas para muitas questões ainda em aberto não só sobre esta, mas também sobre as cadeias de montanhas de um modo geral.

Palavras-chave: Faixa Araçuaí, Orógeno Araçuaí-Congo Ocidental, Evento Brasiliano-Panafricano, Neoproterozóico, Gondwana Ocidental.

\section{INTRODUÇÃO}

Há 30 anos, Almeida (1977) caracterizava os terrenos das margens sudeste e sul do Cráton do São Francisco como um cinturão orogênico brasiliano: "Propomos denominar Araçuai, nome tomado da cidade e do rio nela situados, a faixa de dobramentos brasilianos adjacente às bordas sul e sudeste do Cráton do São Francisco, em Minas Gerais e regiões vizinhas da Bahia" (pg. 357). Foi assim introduzida na literatura 
a definição da Faixa Araçuaí, que nos anos seguintes consolidou-se, não sem acirrados debates sobre correlações estratigráficas e idades de deformação das rochas expostas na Serra do Espinhaço, o seu principal elemento de relevo.

A história da evolução dos conhecimentos sobre a Faixa Araçuaí e toda a região compreendida entre ela e a margem leste brasileira - hoje conjuntamente designadas Orógeno Araçuaí - é revista por PedrosaSoares et al. (2007, neste volume). No curso desta evolução, constitui importante passo o entendimento da Faixa Araçuaí e terrenos adjacentes, a leste, como partes integrantes do sistema orogênico brasilianopanafricano do Gondwana Ocidental. Esta visão foi proporcionada, primeiramente, de maneira panorâmica, por Porada (1989) e, posteriormente, em maiores detalhes, por Pedrosa-Soares et al. (1992). Surge nestes trabalhos o ponto de partida da definição do Orógeno Araçuaí-Congo Ocidental, uma edificação tectônica de características muito peculiares que, na presente síntese, são enfatizadas e comparadas com os atributos comuns a orógenos de um modo geral. Após uma descrição dos componentes do seu arcabouço estrutural, este trabalho contempla ainda uma discussão a respeito do modelo da tectônica "quebra-nozes", proposto para a evolução do Orógeno Araçuaí Congo-Ocidental por Alkmim et al. (2006). Este modelo tem sido objeto de contínuos testes, por ora, através de um esforço de obtenção de novos dados estruturais e geocronológicos, bem como de esclarecimento das relações entre o Orógeno Araçuaí-Congo Ocidental e Faixa Ribeira, que lhe é contígua a sul.

\section{ARAÇUAÍ-CONGO OCIDENTAL: UM ORÓGENO SUI GENERIS}

Justapondo-se as margens continentais leste brasileira e oeste africana, de acordo com a melhor reconstrução cartográfica do Gondwana Ocidental (De Wit et al. 1988), observa-se que a porção norte do Cráton do São Francisco vai de encontro ao segmento setentrional do Cráton do Congo (Fig. 1). Constata-se também que Faixa Araçuaí, juntamente com o segmento crustal compreendido ente ela e a margem continental brasileira (a Província Mantiqueira Setentrional de Almeida et al. 1981 e Almeida \& Hasui 1984), com apenas um pequeno desajuste no setor norte, encontra correspondência na faixa panafricana Oeste Congolesa (Tack et al. 2001). A reconstrução paleogeográfica que deriva deste exercício, realizado por Porada (1989) e outros autores que lhe sucederam (eg., Pedrosa-Soares et al. 1992, Trompete 1994) tem sido continuamente validada, uma vez que:

- confirma-se a natureza cratônica do substrato das margens continentais sul-americana e africana, respectivamente nos trechos correspondentes à Bahia, ao Gabão e a Camarões (Matos 1999, Alkmim 2004);

- não há evidências, nestas mesmas regiões, de ação termal ou deformacional relacionadas ao evento
Brasiliano-Panafricano; os processos orogênicos lá registrados remontam ao Paleoproterozóico (Ledru et al.1994; Feybesse et al. 1998, Silva et al. 2002, Barbosa \& Sabaté 2004, Lerouge et al. 2006);

- estudos paleomagnéticos realizados por D'AgrellaFilho et al. (1990, 2004) e Renne et al. (1990) indicam paleopolos praticamente coincidentes para os crátons do São Francisco e do Congo no tempo préneoproterozóico;

- um grande número de dados estratigráficos, petrológicos e geocronológicos confirma, sem qualquer dúvida, a região compreendida entre o Cráton do São Francisco e margem leste brasileira como zona orogênica brasiliana e o mesmo é válido para a Faixa Oeste-Congolesa;

- em que pese diferenças marcantes entre os seus registros estratigráficos até o período Criogeniano (Pedrosa-Soares et al. 2008), a história tectônica das zonas orogênicas brasiliana e panafricana, acima mencionadas, guardam muitas similaridades e elas podem, sem maiores problemas, ser entendidas como contrapartes de um mesmo sistema.

Uma vez confirmada, essa reconstrução implica na existência de duas feições geotectônicas indissociáveis: o Cráton São Francisco-Congo (com conexão em ponte, estável desde o Paleoproterozóico, Porada 1989) e o orógeno brasiliano-panafricano Araçuaí-Congo Ocidental (Pedrosa-Soares et al. 2001). Visto sob esta perspectiva, o Orógeno Araçuaí-Congo Ocidental apresenta-se em mapa com um contorno linguóide ou em ferradura, dotado de vergências centrífugas, dirigidas para as zonas cratônicas que o abraçam quase completamente (Fig. 1). Somente por estes traços gerais o Orógeno Araçuaí-Congo Ocidental difere muito de construções tectônicas equivalentes, tanto modernas, quanto antigas. Os orógenos comuns não são confinados por áreas cratônicas e os seus traços estruturais não descrevem trajetórias fechadas, como se vê na Figura 1.

Com os atributos mencionados, era de se esperar que o Orógeno Araçuaí-Congo Ocidental tivesse evoluído em ambiente totalmente ensiálico. Tal não é o caso. Como demonstrado por Pedrosa-Soares et al. (1992, 1998, 2001) e Pedrosa-Soares \& Wiedemann-Leonardos (2000), fazem parte da sua constituição granitóides de arco magmático relacionado a subducção e ofiolitos, ambos de idade neoproterozóica, indicando, portanto, geração e consumo de litosfera oceânica durante o seu desenvolvimento.

Uma outra particularidade do orógeno em foco é o volume anomalamente alto de rochas graníticas geradas durante a sua edificação, especialmente aquelas derivadas de fusão crustal durante o estágio colisional (a suíte G2 de Pedrosa-Soares \& Wiedemann-Leonardos 2000, Noce et al. 2000), o que requer magnitudes de deformação e espessamento crustal, a primeira vista, incompatíveis com a sua natureza confinada. 


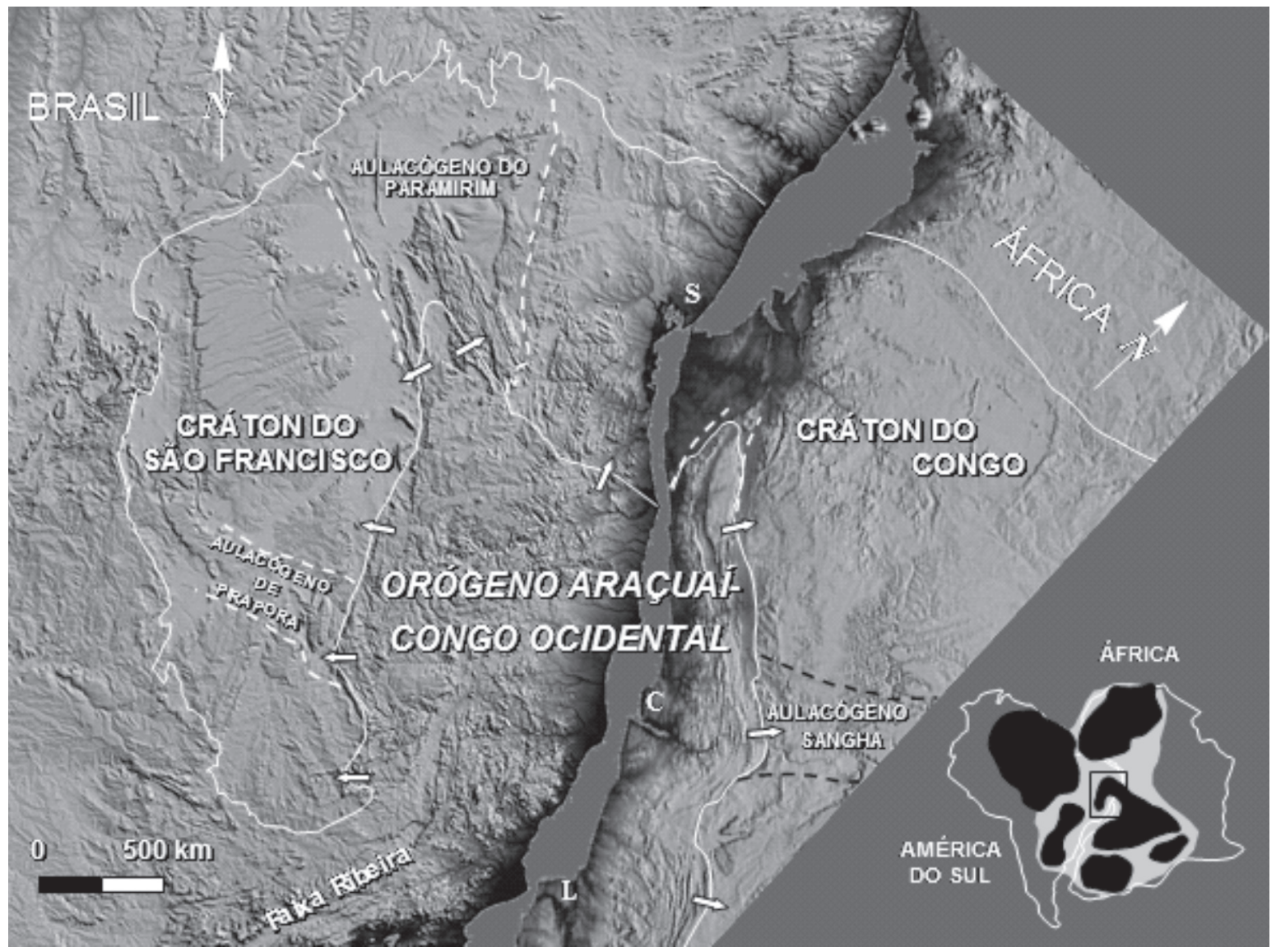

Figura 1. O Orógeno Araçuai-Congo Ocidental no cenário do Gondwana, reconstruído pela justaposição de modelos digitais de terreno da porção leste do Brasil e costa oeste africana.

L: Luanda; C: Cabinda; S: Salvador (Brasil).

\section{ARCABOUCO ESTRUTURAL}

O conhecimento hoje disponível sobre o Orógeno Araçuaí-Congo Ocidental permite a sua subdivisão em dez compartimentos tectônicos, os quais se distinguem em função da orientação espacial, significado cinemático e história de nucleação das estruturas dominantes (Alkmim et al. 2006). São eles os seguintes (Fig. 2): i) o Cinturão de Cavalgamentos da Serra do Espinhaço Meridional; ii) a Zona de Cisalhamento da Chapada Acauã, iii) a zona de dobramentos de Salinas; iv) o Corredor Transpressivo de Minas Novas; v) a saliência do Rio Pardo e sua zona de interação com o Aulacógeno do Paramirim; vi) o Bloco de Guanhães; vii) a Zona de Cisalhamento de Dom Silvério e estruturas associadas; viii) a Zona de Cisalhamento de Itapebi e estruturas associadas; ix) o núcleo cristalino (i.e., a zona interna de alto grau que representa o núcleo do orógeno); e x) o Cinturão Oeste-Congolês.

A Faixa Araçuaí, tal como definida por Almeida (1977), engloba os oito primeiros compartimentos acima listados e, juntamente com a Faixa OesteCongolesa, constitui o cinturão metamórfico externo do orógeno (Fig. 2). Pelo fato da porção brasileira abarcar aproximadamente $65 \%$ da área do Orógeno Araçuaí-Congo Ocidental, compreendendo nove dos dez compartimentos mencionados, ela é designada Orógeno Araçuaí (Pedrosa-Soares et al. 2007, 2008).
Dentre os compartimentos tectônicos discriminados, o Cinturão de Cavalgamentos da Serra do Espinhaço Meridional é, de longe, o melhor estudado, tanto do ponto de vista estratigráfico, como estrutural. Em contraposição, o núcleo cristalino é o setor que ainda carece de muitos estudos. É o mais extenso e estruturalmente o mais complexo compartimento do orógeno. Aqui visto como uma peça única sofrerá, certamente, subdivisões, na medida em que novos dados forem surgindo.

Nas seções seguintes descrevem-se, sucintamente, as características gerais dos dez compartimentos tectônicos do orógeno. As unidades estratigráficas neles envolvidas são analisadas por Pedrosa-Soares $e t$ al. (2007, neste volume).

\section{O Cinturão de Cavalgamentos da Serra do Espinhaço Meridional}

O Cinturão de Cavalgamentos da Serra do Espinhaço Meridional margeia o Cráton do São Francisco pelo leste por cerca de $700 \mathrm{~km}$ (Fig. 3). Com direção geral meridiana, envolve o embasamento ArqueanoPaleoproterozóico, as rochas supracrustais dos supergrupos Espinhaço e São Francisco (Dussin \& Dussin 1995, Uhlein et al. 1998), além de um considerável 


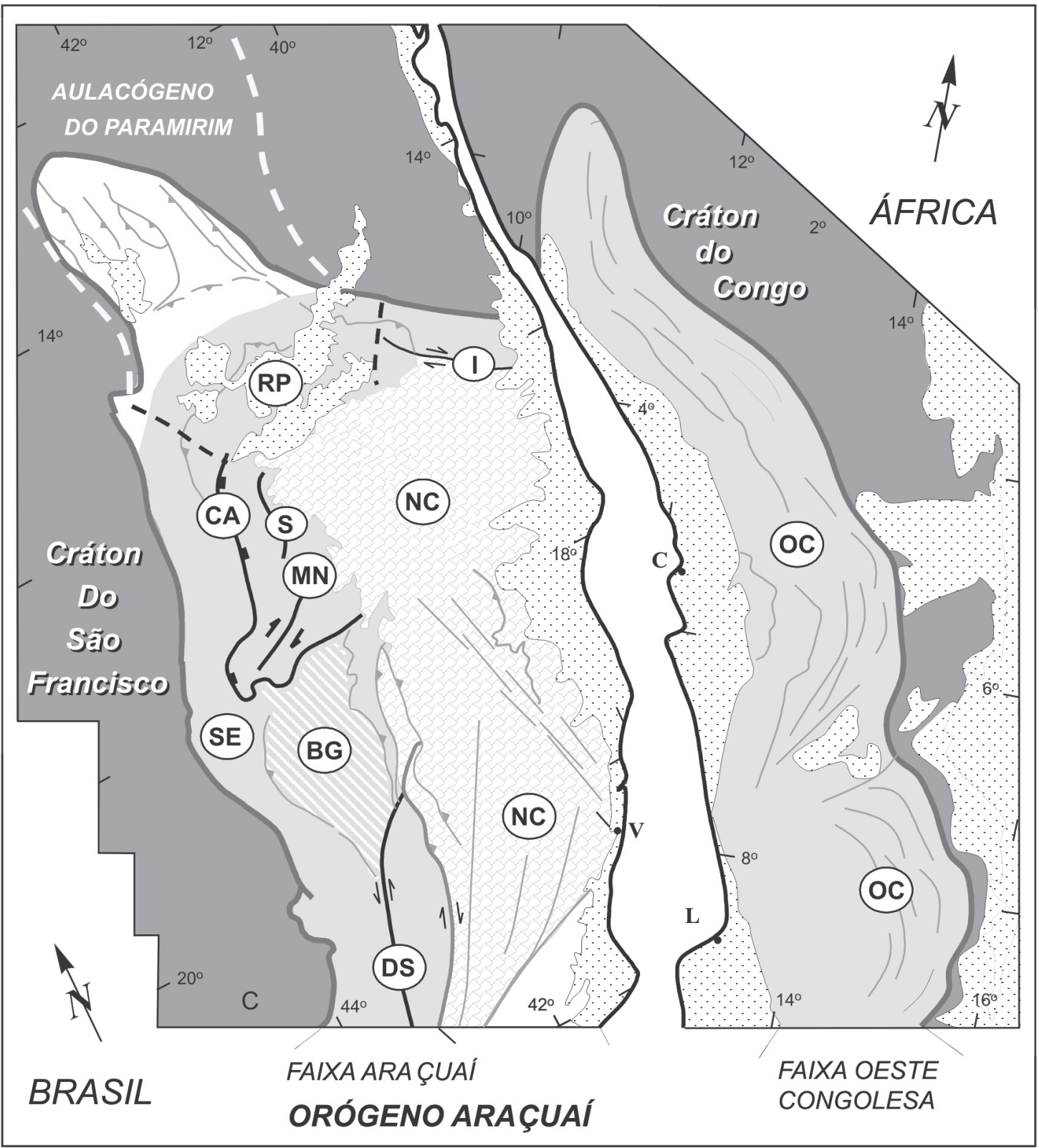

Figura 2. Compartimentos tectônicos do Orógeno Araçuai-Congo Ocidental: SE: Cinturão de Cavalgamentos da Serra do Espinhaço Meridional; CA: Zona de Cisalhamento da Chapada Acauã; S: Zona de dobramentos de Salinas; MN: Corredor transpressivo de Minas Novas; RP: Saliência do Rio Pardo e zona de interação com o Aulacógeno do Paramirim; BG: Bloco de Guanhães; DS: Zona de Cisalhamento de Dom Silvério;

I: Zona de Cisalhamento de Itapebi; NC: núcleo cristalino; OC: Faixa Oeste-Congolesa.

volume de intrusões máficas pós-Espinhaço. Tem a sua vergência dirigida sistematicamente para o cráton adjacente, e é dominado por falhas de empurrão e dobras de orientação preferencial NS, nucleadas em até duas fases de deformação co-axiais e progressivas, que refletem um encurtamento geral E-W. As lineações de estiramento estão preferencialmente orientadas na direção E-W e os indicadores cinemáticos associados também mostram transporte tectônico dirigido para oeste. (Uhlein et al. 1986, Uhlein 1991, Dussin \& Dussin 1995, Grossi-Sad et al. 1997). A fase de deformação principal registrada no cinturão é acompanhada de metamorfismo nas condições de fácies xisto verde a anfibolito (Uhlein 1991, Dussin \& Dussin 1995, Pedrosa-Soares et al. 2001).
No extremo norte do cinturão, as falhas reversas e de empurrão próximas ao seu limite oeste infletem para NNW e continuam pelo interior do Cráton do São Francisco, para tomar parte, mais a norte, do segmento sul, invertido, do Aulacógeno do Paramirim (Cruz \& Alkmim 2006). Já as porções mais internas do seu segmento norte rotacionam-se progressivamente para NE e vão formar a Saliência do Rio Pardo (Fig. 3).

O cinturão da Serra do Espinhaço é acompanhado, no interior do Cráton do São Francisco, por uma zona de dobramentos e empurrões de largura média de 45 km que afeta os supergrupos Espinhaço e São Francisco (Fig. 3), mas não envolve o embasamento (Alkmim et al. 1996). Esta zona pode ser entendida como o cinturão epidérmico de antepaís do orógeno, a qual, em acordo 


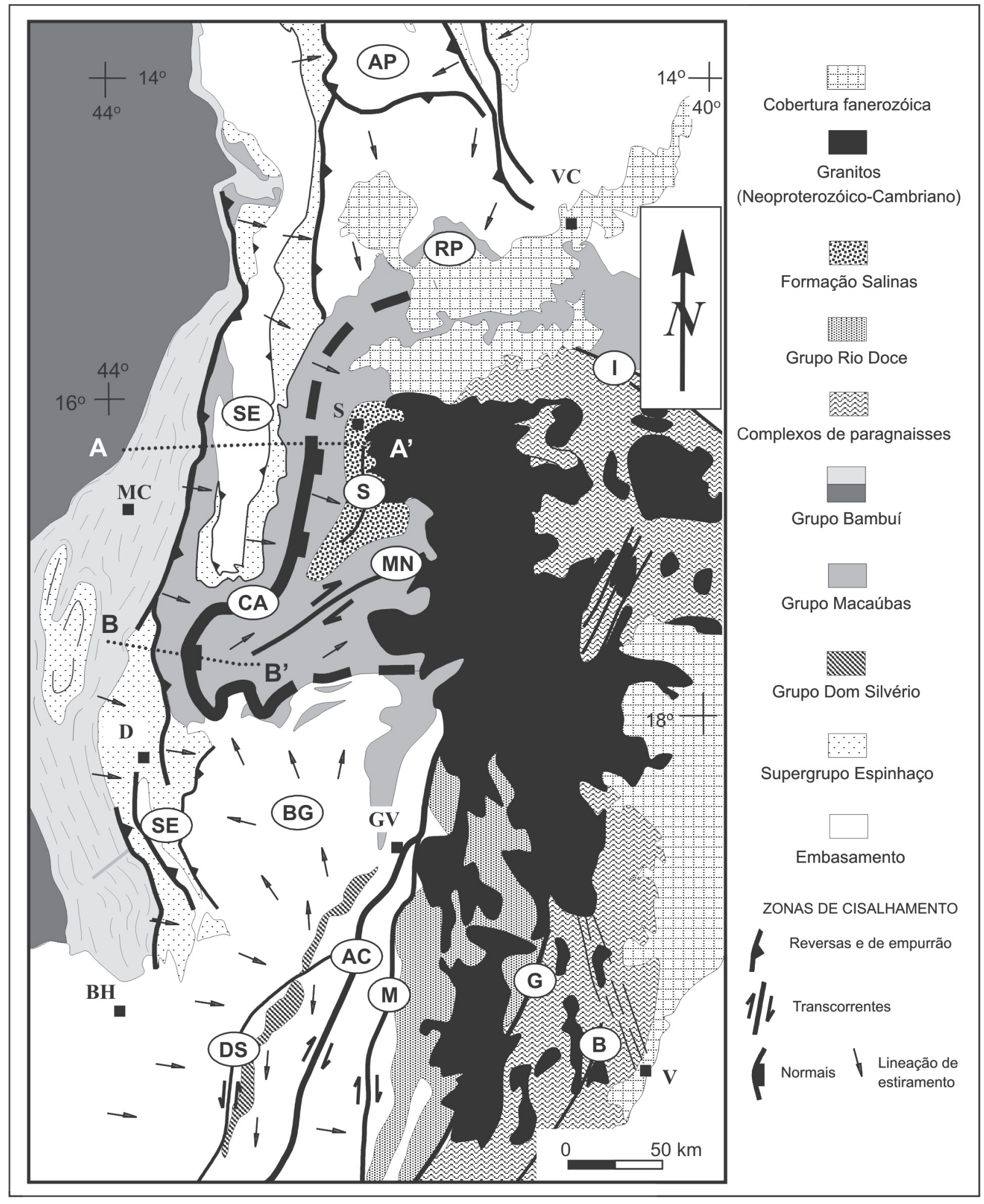

Figura 3. Mapa tectônico esquemático do Orógeno Araçuaí, enfatizando os seus compartimentos e grandes zonas de cisalhamento. SE: Cinturão de cavalgamentos da Serra do Espinhaço Meridional;

CA: Zona de Cisalhamento da Chapada Acauã; S: Zona de dobramentos de Salinas; MN: Corredor transpressivo de Minas Novas; RP: Saliência do Rio Pardo e zona de interação com o Aulacógeno do Paramirim; BG: Bloco de Guanhães; DS: Zona de Cisalhamento de Dom Silvério; I: Zona de Cisalhamento de Itapebi; AC: Zona de Cisalhamento de Abre Campo; M: Zona de Cisalhamento de Manhuaçu; G: Zona de Cisalhamento de Guacuí; B: Zona de Cisalhamento de Batatal. Confecionado com base em Pedrosa-Soares et al. 2001. 
com a proposição de Almeida (1977), é entendida como parte do domínio cratônico.

No seu segmento central, o cinturão da Serra do Espinhaço exibe uma saliência que é seguida, com ligeira defasagem, pelo cinturão de antepaís adjacente (Fig. 3). Da mesma forma que em outras faixas orogênicas, esta saliência fica situada no setor onde a pilha sedimentar envolvida exibe a sua maior espessura (Macedo \& Marshak 1999, Rolim \& Alkmim 2004). Em função disso e de informações geofísicas adicionais pode-se inferir a presença de baixo estrutural de orientação WNW-ESSE na zona cratônica imediatamente adjacente, feição interpretada por Alkmim \& Cruz (2005) como uma calha rifte não exposta, o Aulacógeno de Pirapora. Uma feição muito semelhante é o Aulacógeno Sangha, no Cráton do Congo (ver adiante).

Da mesma forma que ocorre com o Orógeno Araçuaí como um todo, na medida em que se avança para sul, o cinturão vai sendo exposto em níveis cada vez mais profundos, até perder as rochas de baixo grau metamórfico da cobertura neoproterozóica. A sua terminação sul, exposta ao nível do substrato, compreende a porção leste do Quadrilátero Ferrífero, marcada por falhas de empurrão e dobras vergentes para leste (Almeida 1977, Peres et al. 2004).

\section{A Zona de Cisalhamento da Chapada Acauã}

Assim denominada por fazer parte do substrato da grande chapada situada a leste da Serra do Espinhaço
Meridional, esta zona de cisalhamento compreende uma faixa de largura variável entre 15 e $35 \mathrm{~km}$ e traço curvilíneo que se estende desde a região de Itamarandiba, passando por São Gonçalo do Rio Preto, até a região de Salinas, norte de Minas Gerais (Gradim et al. 2005, Marshak et al. 2006, Alkmim et al. 2006). A sua continuidade a noroeste de Salinas é apenas inferida (Fig. 3 e 4).

A Zona de Cisalhamento da Chapada Acauã é marcada por uma rica assembléia de estruturas, dentre as quais se destacam trens de dobras vergentes para leste, cujas superfícies envoltórias mergulham no mesmo rumo. A estas dobras se associa uma clivagem de crenulação, cuja orientação preferencial é 290/50. Zonas de cisalhamento dúctil-rúpteis normais e tension gashes verticais são outros elementos muito freqüentes no seu interior (Grossi-Sad et al. 1997, Gradim et al. 2005, Marshak et al. 2006, Santos et al. 2007). Todas estas estruturas são de segunda geração nos domínios onde ocorrem, ou seja, se superpõem às dobras, zonas de cisalhamento e foliações da fase de deformação principal da zona externa do orógeno, a qual se associa o transporte tectônico dirigido para oeste.

A orientação espacial e o sentido de cisalhamento das suas estruturas implicam em uma natureza distensional para a Zona de Cisalhamento da Chapada Acauã. Considerando sua relação de corte com os elementos da deformação principal, sin-metamórfica, do orógeno, Marshak et al. (2006) interpretam-na como uma manifestação do colapso gravitacional do Orógeno Araçuaí, que em outros compartimentos é

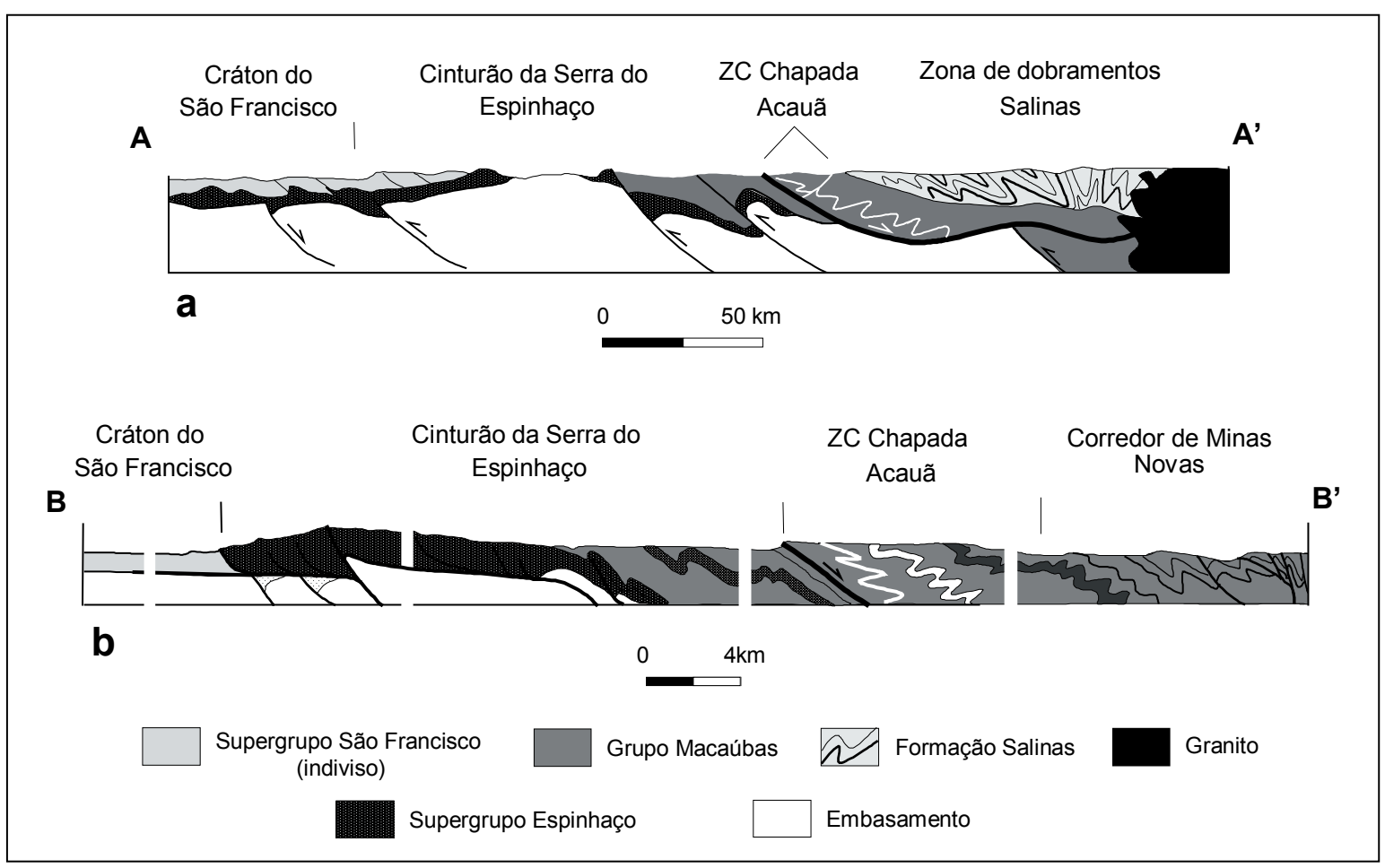

Figura 4. Seções geológicas esquemáticas da porção oeste do Orógeno Araçuaí, cuja localização é indicada no mapa da Figura 3. Note que a seção da Fig. 4 boi encurtada para simplificação em vários de seus segmentos. Adaptado de Alkmim et al. (2006). 
representado por estruturas semelhantes (Peres et al. 2004, Cruz \& Alkmim 2006) e pelas granitogêneses G4 e G5 (Pedrosa-Soares \& Wiedemann-Leonardos 2000, Pedrosa-Soares et al. 2007).

O exame do mapa da Figura 3 e das seções da Figura 4 mostra que a função principal desempenhada pela Zona de Cisalhamento da Chapada Acauã no cenário do orógeno é o abatimento de todo o bloco, constituído por rochas Macaúbas e Salinas, situado a leste da Serra do Espinhaço Meridional e a norte do Bloco de Guanhães. Este fato explica a preservação da unidade sedimentar mais jovem do orógeno (a Formação Salinas) nas porções internas e junto ao núcleo cristalino, uma ocorrência muito pouco provável na ausência de uma considerável subsidência pós-colisional.

\section{A Zona de Dobramentos de Salinas}

Limitada, a oeste, pela Zona de Cisalhamento Chapada Acauã, a leste por um conjunto de plútons amalgamados da Suíte G4 e, a sul, pelo Corredor Transpressivo de Minas Novas (Fig. 3 e 4), a Zona de Dobramentos de Salinas envolve rochas da porção superior do Grupo Macaúbas (formações Nova Aurora, Chapada Acauã e Ribeirão da Folha) e, principalmente, a Formação Salinas, cuja idade máxima de sedimentação é $588 \pm 24 \mathrm{Ma}$ (Pedrosa-Soares \& Oliveira 1997, Lima et al. 2002, Pedrosa-Soares et al. 2007, 2008). É característico deste compartimento um conjunto de dobras e raras falhas de empurrão de orientação geral NNE e dupla vergência (Fig. 4), dirigida tanto para WNW, quanto para ENE (Uhlein 1991, Santos et al. 2007), compondo desta forma um arranjo análogo àquele observado em cunhas de empurrões naturais e experimentais (Dahlen et al. 1984). As dobras, cujas dimensões vão da escala centimétrica a quilométrica, associam-se, localmente, a clivagem de plano axial, lineação de estiramento e intensa boudinagem (Santos et al. 2007).

Em estudo recente sobre a história tectônica da Formação Salinas, Santos et al. (2007) descrevem três fases deformacionais, sendo a primeira delas sin-deposional, a segunda, a principal e responsável pela geração das estruturas características da zona de dobramentos, e a terceira induzida pelas intrusões graníticas G4 que limitam a ocorrência da unidade pelo leste. A segunda fase de deformação foi acompanhada do evento metamórfico regional do orógeno, que lá atingiu as condições da fácies anfibolito médio, embora ocorram zonas de fácies xisto verde com estruturas sedimentares muito bem preservadas (Lima et al. 2002).

Sabendo-se que a idade máxima para a deposição dos sedimentos Salinas é de $588 \pm 24$ Ma (PedrosaSoares et al. 2008), e levando-se em consideração o fato de ter ela experimentado a deformação principal sinmetamórfica do orógeno, cujo clímax teria sido atingido entre 580 e $560 \mathrm{Ma}$ (Pedrosa-Soares et al. 2001, Noce et al. 2004), é forçoso concluir que esta unidade depositou-se praticamente em concomitância com a fase colisional edificadora do orógeno. Pode-se dizer, assim, que a Formação Salinas representa uma assembléia sin-orogênica ou flysch. De fato, se comparada a sucessões desta natureza presentes em vários orógenos, especialmente no Alpino, a Formação Salinas mostra grandes similaridades, tanto em constituição, quanto em acervo estrutural (Santos et al. 2007).

\section{O Corredor Transpressivo de Minas Novas}

O Corredor Transpressivo de Minas Novas (Fig. 3), caracterizado por Pedrosa-Soares (1995), é uma larga zona de deformação transcorrente dextral de orientação geral NE-SW, desenvolvida sobre rochas do Grupo Macaúbas e Formação Salinas. Na sua extremidade SW, o corredor é cortado pela Zona de Cisalhamento da Chapada Acauã e, em direção a NE, perde progressivamente definição no interior da província granítica do núcleo cristalino do orógeno. O metamorfismo regional varia da fácies xisto verde a anfibolito médio, sob regime de baixa pressão (Costa 1989, Pedrosa-Soares et al. 1996).

A geometria geral do corredor em seção transversal é em flor positiva, desenhada por uma foliação penetrativa, em geral, paralela ao acamamento das unidades envolvidas. No ramo NW as foliações mergulham para SE; no ramo oposto verifica-se o contrário. Em direção ao centro a foliação tem o seu mergulho progressivamente acentuado, até atingir a verticalidade. Neste setor, podem ser observadas grandes dobras isoclinais de planos axiais verticais, cujas charneiras caem preferencialmente para NE. As lineações de estiramento mostram obliqüidades muito variáveis sobre os elementos do corredor e um caimento preferencial de $30^{\circ}$ para NE.

\section{A Saliência do Rio Pardo e sua interação com o Aulacógeno do Paramirim}

$\mathrm{Na}$ altura do paralelo $16^{\circ} \mathrm{S}$, na porção norte do orógeno, as estruturas de orientação geral NS do Cinturão de Cavalgamentos da Serra do Espinhaço Meridional infletem progressivamente em direção a $\mathrm{NE}$, descrevendo um grande arco com a convexidade voltada para norte. Trata-se da Saliência do Rio Pardo, na qual estão envolvidas rochas do Supergrupo Espinhaço e Grupo Macaúbas (Fig. 3). No interior da saliência, identificam-se estruturas de duas gerações que se interferem, dando origem a padrões em domos e bacias (Almeida et al. 1978, Cruz \& Alkmim 2006). A geração mais antiga está associada a transporte tectônico dirigido para norte, em direção ao cráton; a mais jovem reflete um encurtamento geral na direção WSW-ENE (Cruz \& Alkmim 2006).

O front de deformações brasilianas materializado pela Saliência do Rio Pardo avança em direção a norte, adentrando a calha do Aulacógeno do Paramirim, feição intracratônica que engloba a Serra do Espinhaço 
Setentrional, Vale do São Francisco e Chapada Diamantina, no Estado da Bahia (Cruz \& Alkmim 2006). Verifica-se ali um rico e complexo acervo de estruturas que afetam o substrato cratônico e as rochas supracrustais dos supergrupos Espinhaço e São Francisco. A inversão do aulacógeno deu-se nas mesmas fases registradas na Saliência do Rio Pardo, ou seja, primeiramente movimentos dirigidos para norte (Cruz \& Alkmim 2006) e, posteriormente, uma compressão geral WSW-ENE (Danderfer 2000, Cruz 2004).

\section{O Bloco de Guanhães}

O Bloco de Guanhães corresponde a um grande alto estrutural que expõe o embasamento do orógeno a sudeste do Cinturão de Cavalgamentos da Serra do Espinhaço Meridional (Fig. 3 e 5). É constituído por gnaisses TTG de idades similares aos do substrato do Cráton do São Francisco (Noce et al. 2003). Contém, além dos gnaisses arqueanos, seqüências metassedimentares e grandes plútons graníticos da Suíte Borrachudos (1,75 Ga; Chemale Jr. et al. 1977, Dussin 2000, Silva et al., 2002, Noce et al. 2003). Ao se examinar a distribuição das unidades do Grupo Macaúbas nas suas adjacências, nota-se que somente as unidades mais jovens e distais do grupo, as formações Chapada Acauã e Ribeirão da Folha, fazem com ele contato pelo norte (Pedrosa Soares et al. 2001, 2007, Gradim et al. 2005). Tal fato constitui um indício de que o Bloco de Guanhães deve ter atuado como alto estrutural já à época do rifte Macaúbas.

Do ponto de vista estrutural, o bloco pode ser subdividido em três domínios que se distribuem em faixas alongadas na direção NS (Alkmim et al. 2006). O domínio oeste é caracterizado por uma série de falhas reversas e de empurrão com direção NS, que lançam lascas do embasamento sobre as rochas Espinhaço, situadas mais a oeste. O domínio leste é também marcado por falhas de empurrão de direção NS que colocam rochas da Formação Ribeirão da Folha, do Grupo Macaúbas, sobre gnaisses do embasamento. O compartimento central é balizado pelas zonas de cisalhamento Pedra Branca, Sabinópolis e Virgolândia de direção preferencial NS (Fig. 5). Tais zonas mostram duas fases de movimentação distintas: a mais antiga, de sentido reverso e a mais nova de sentido normal a normal-dextral, o qual é interpretado como uma outra manifestação do colapso gravitacional do orógeno (Peres et al. 2004). As rochas expostas no domínio central experimentaram condições metamórficas consideravelmente mais elevadas do que os domínios leste e oeste. Elas exibem paragêneses minerais típicas da fácies anfibolito alto e foram migmatitizadas entre 519 e $507 \mathrm{Ma}$ (Noce et al. 2003). Em contraste, idades de resfriamento K-Ar disponíveis para os domínios laterais, onde vigoram condições metamórficas da fácies xisto verde, situam-se entre 530 e $540 \mathrm{Ma}$, e refletem o metamorfismo regional ocorrido entre 580 e $560 \mathrm{Ma}$ (Noce et al. 2003). Além disso, determinações Ar-Ar em flogopitas provenientes da Zona de Cisalhamento Pedra Branca forneceram uma idade de $509 \pm 2 \mathrm{Ma}$ (Ribeiro-Althoff et al. 1977), compatível com aquelas da migmatitização no domínio central. Todos estes fatos indicam que a parte central do Bloco de Guanhães expõe um nível crustal consideravelmente mais profundo do que as porções adjacentes a oeste e leste, e que o seu soerguimento deu-se por volta de $510 \mathrm{Ma}$, idade provável do colapso gravitacional do orógeno (Peres et al. 2004).

\section{A Zona de Cisalhamento Dom Silvério e estruturas associadas}

AZona de Cisalhamento Dom Silvério (Endo 1997) marca os limites extremo sudeste do Bloco de Guanhães e leste do Cinturão de Cavalgamentos da Serra do Espinhaço Meridional (Fig. 3). Possui traço N-S nos seus setores sul e central, infletindo para NNE-SSW a norte, onde é truncada pela Zona de Cisalhamento Abre Campo, que marca o limite oeste do núcleo cristalino do orógeno (Peres et al. 2004) Trata-se de uma zona transcorrente sinistral ladeada por domínios caracterizados por uma foliação de baixo ângulo em associação com uma lineação mineral posicionada na direção NS, que refletem, em conjunto, um transporte geral para $\mathrm{N}$, relativo à fase de deformação mais antiga até agora identificada no orógeno (Peres et al., 2004). O compartimento situado a leste da Zona de Cisalhamento Dom Silvério corresponde a uma calha sinformal suave que hospeda rochas envolvidas em intenso dobramento vergente para W. A oeste, persistem as foliações de baixo ângulo e lineações N-S, as quais, na medida em se avança em direção ao Cráton do São Francisco, passam, gradualmente, a uma foliação de médio ângulo e uma lineação com caimento para $\mathrm{E}$, associadas a transporte para W (Peres et al. 2004).

\section{A Zona de Cisalhamento de Itapebi e estruturas associadas}

A Zona de Cisalhamento de Itapebi é um sistema transpressivo dextral, situado na porção nordeste do orógeno (Fig. 3). Afeta a Suíte Salto da Divisa (ca. $880 \mathrm{Ma}$, Silva et al. 2007), o Complexo Jequitinhonha e o embasamento arqueano-paleoproterozóico (Mascarenhas et al. 1979, Pedrosa-Soares et al. 1992, Paixão \& Perrella 2004, Sampaio et al. 2004, Uhlein 2004). A leste, conecta-se à Saliência do Rio Pardo e suas falhas mais externas (setentrionais) marcam a fronteira do Orógeno Araçuaí com o Cráton do São Francisco. Tanto nas falhas de empurrão mais externas, quanto na zona transcorrente central do sistema, verificam-se evidências de uma fase de reativação normal-sinistral a sinistral.

\section{O núcleo cristalino do orógeno}

A descontinuidade geofísica de Abre Campo 


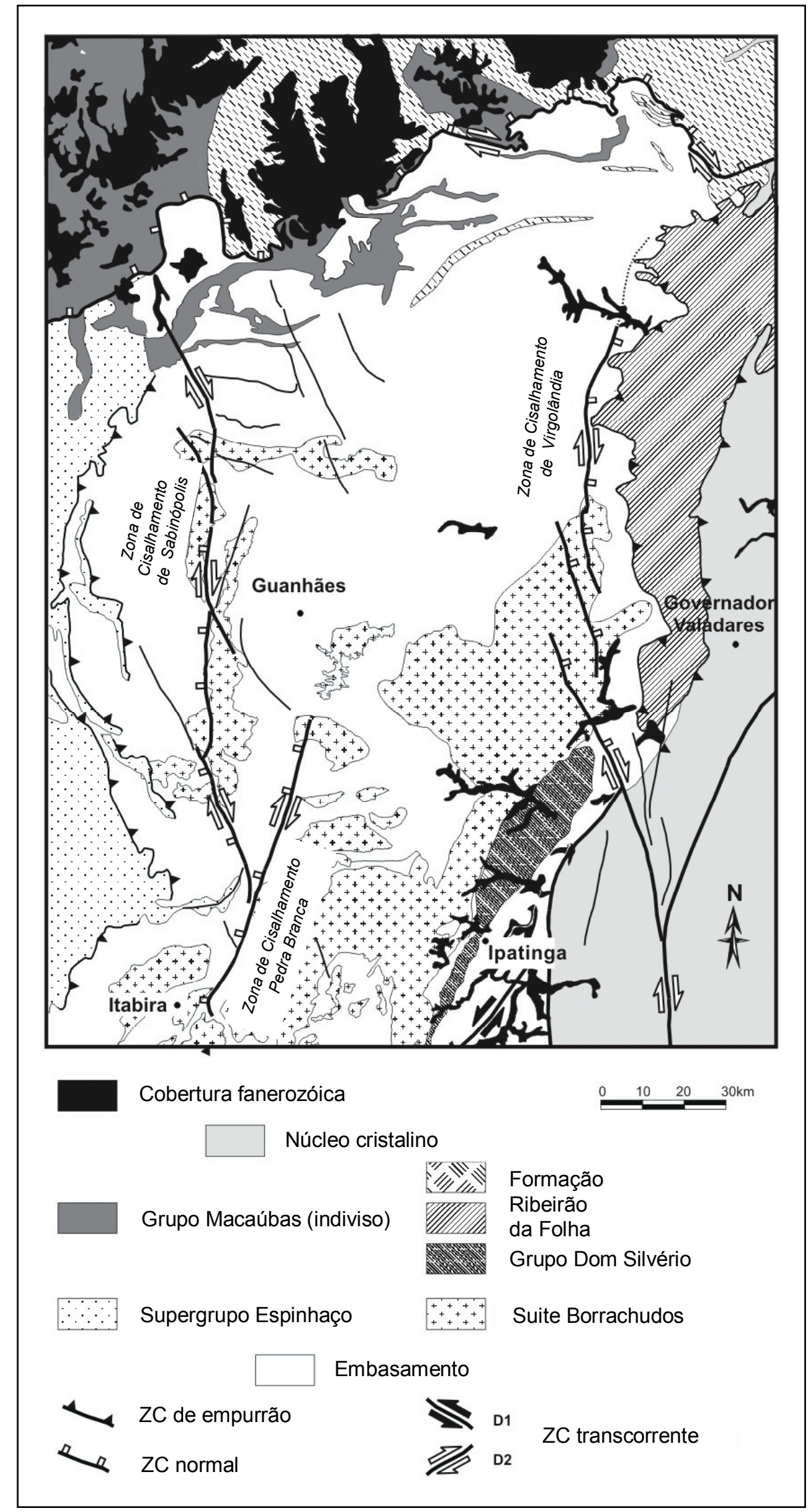

Figura 5. Mapa geológico simplificado da região do Bloco de Guanhães, enfatizando as suas grandes zonas de cisalhamento. 
(Haralyi \& Hasui 1982) marca uma mudança substancial nas características do orógeno (Fig. 3). A leste desta estrutura, o substrato é de idade paleoproterozóica (o Complexo Juiz de Fora), o metamorfismo é dominantemente de fácies anfibolito alto a granulito, e as demais unidades presentes são suítes graníticas pré- a pós-colisionais (G1 a G5) e assembléias metavulcanosedimentares e metassedimentares mais jovens que 630 Ma, correspondentes ao Grupo Rio Doce e complexos paragnáissicos. Estes não possuem correlativos na Faixa Araçuaí (s.s.) e representam sedimentos depositados em bacias diretamente relacionadas ao arco magmático do orógeno homônimo (Noce et al. 2004, Pedrosa-Soares et al. 2007, 2008, Vieira 2007). É assim constituído o que se poderia chamar de núcleo cristalino, ou núcleo de alto grau do orógeno, que se estende até a margem continental brasileira (Fig. 3).

A porção do núcleo cristalino melhor conhecida do ponto de vista estrutural é a meridional, que tem como elementos tectônicos principais quatro grandes zonas transcorrentes dextrais, dentre elas as zonas de cisalhamento de Abre Campo, Manhuaçu, Guacuí e Batatal (Campos-Neto \& Figueiredo 1995, Fischel et al. 1998; Cunningham et al. 1996, 1998; Brueckner 2000). Estas estruturas estão associadas a largas faixas miloníticas que se superpõem, com paragêneses de mais baixo grau (em geral da fácies xisto verde), a uma trama associada a transporte tectônico dirigido para norte (reliquiar) ou, mais frequentemente, para leste (Cunningham et al. 1998, Peres et al. 2004).

Dentre as zonas transcorrentes acima mencionadas, a de Abre Campo deve representar uma sutura, não só paleoproterozóica, como indicado pela separação que faz de terrenos do embasamento (Cunningham et al. 1998, Fischel et al. 1998, Brueckner 2000, Noce et al. 2007), mas também neoproterozóica, pelo fato de limitar pelo oeste, em todo o seu traçado, a ocorrência dos granitóides pré-colisionais G1 (Pedrosa-Soares et al. 2007). Além disso, o seu segmento norte, na região de Governador Valadares, conserva o seu caráter

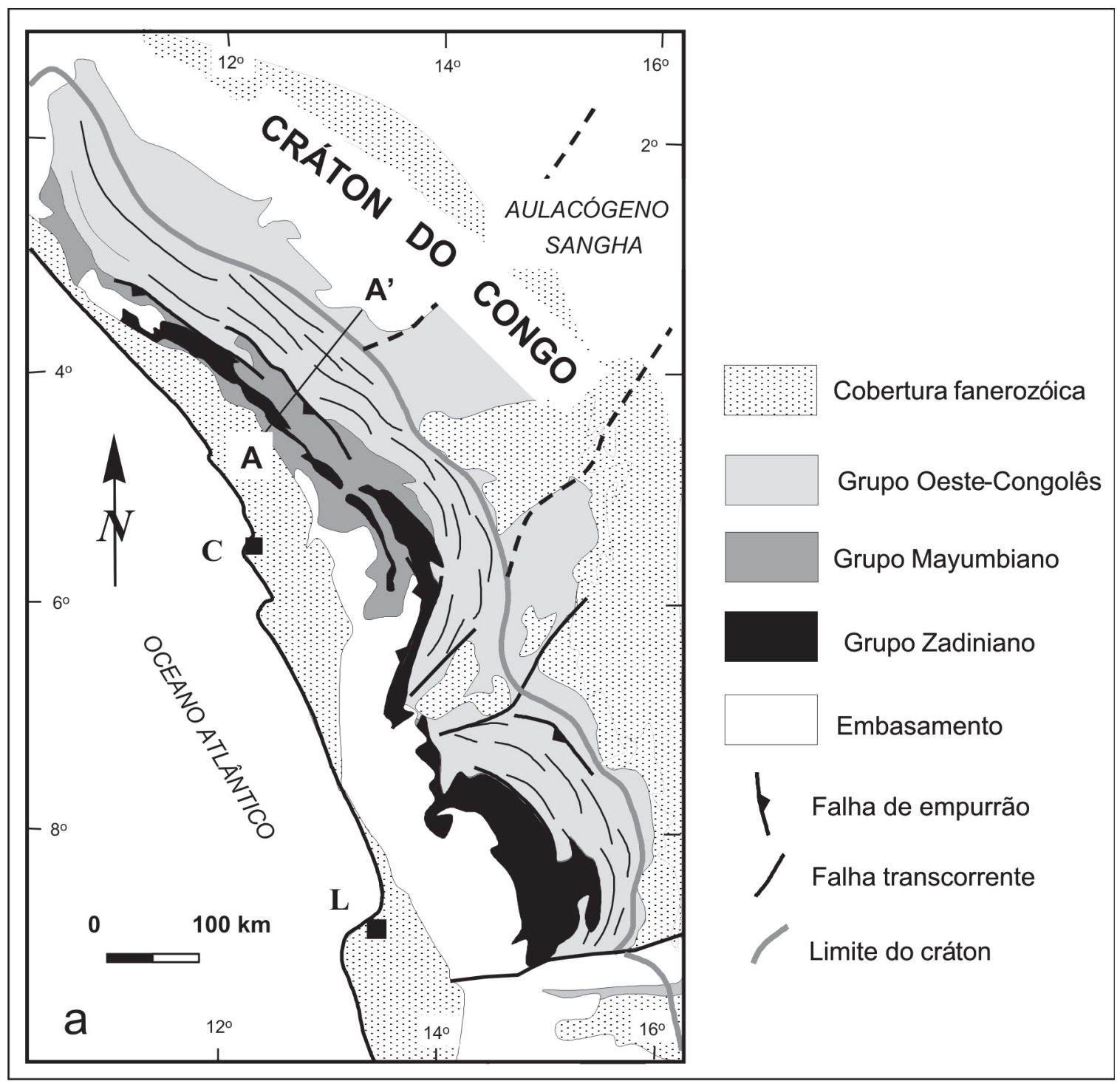

Figura 6. Mapa geológico simplificado da Faixa Oeste-Congolesa, confeccionado com base em Maurin (1993) e Tack et al. (2001). Adaptado de Alkmim et al. (2006). 
original de zona de empurrão, que coloca corpos da Suíte G1 sobre sedimentos marinhos profundos da Formação Ribeirão da Folha (Pedrosa-Soares et al. 2001, 2007, Peres et al. 2004, Vieira 2007).

No setor setentrional do núcleo cristalino, predomina uma deformação pervasiva de grande magnitude, que se expressa por uma foliação penetrativa com mergulhos baixos a moderados. Uma zona de inversão do mergulho da foliação regional e da vergência a ela relacionada se situa em torno do meridiano $41^{\circ} 30^{\prime} \mathrm{W}$, entre os paralelos $17^{\circ}$ e $19^{\circ} \mathrm{S}$. O setor a ocidente desta zona registra transporte tectônico de topo predominantemente para oeste, rumo ao Cráton do São Francisco, ao passo que o setor oriental apresenta vergência majoritariamente para leste (Pedrosa-Soares et al. 2001, 2006, Vieira 2007).

Um elemento do setor setentrional que muito se destaca em mapas de relevo e imagens de sensores remotos é um feixe de lineamentos que se estende por mais de $200 \mathrm{~km}$ na direção NNW a partir de Vitória. Trata-se, aparentemente, de um conjunto de estruturas rúpteis, que inclui diques básicos de idade cretácica (Radambrasil 1983, Novais et al. 2004).

\section{A Faixa Oeste-Congolesa}

A Faixa Oeste-Congolesa estende-se na direção NW, por cerca de $1200 \mathrm{~km}$, ao longo da costa africana do Gabão, Republica Popular do Congo e Angola (Fig. 2 e 6). Constitui um típico cinturão de cavalgamentos e dobramentos vergentes para o antepaís cratônico, que em mapa exibe duas grandes saliências, uma delas na zona de interação com o Aulacógeno Sangha ou Bacia de Comba (Alvarez \& Maurin 1991, Tack et al. 2001).

Na Faixa Oeste-Congolesa ocorrem as seguintes unidades (Cahen et al. 1984, Trompette 2004, Tack et al. 2001):

- o embasamento representado por rochas arqueanas e pelo Supergrupo Kimeziano de idade paleoproterozóica, constituído por gnaisses, anfibolitos e rochas supracrustais metamorfisadas na fácies anfibolito;

- o Grupo Zadiniano, composto por arenitos e pelitos, capeados por riolitos e basaltos extrudidos entre 1000 e $920 \mathrm{Ma}$, e metamorfizados em torno de $570 \mathrm{Ma}$;

- o Grupo Mayumbiano, que consiste essencialmente de efusivas ácidas acumuladas entre 920 e $910 \mathrm{Ma}$;

- o Grupo Oeste-Congolês, que engloba uma espessa seqüência de tochas terrígenas e carbonáticas, incluindo dois horizontes de diamictitos glaciogênicos.

Todas estas unidades vulcânicas e sedimentares estão englobadas no Supergrupo Congo Ocidental que registra, desde a fase rifte toniana, o completo desenvolvimento de uma bacia de margem passiva (Tack et al. 2001).

Da zona cratônica indeformada (Fig. 6 e 7), recoberta pelos sedimentos mais jovens do Grupo Oeste-Congolês, passa-se, a seguir, a uma faixa de dobramentos de antepaís e atinge-se o cinturão metamórfico que envolve, em sucessivas lascas de empurrão, unidades cada vez mais velhas, primeiro do Grupo Mayumbiano, seguidas do Grupo Zadiniano e, por fim, do embasamento Kimeziano (Maurin 1993, Trompette 1994, Tack et al. 2001). A terminação norte da faixa, aparentemente deslocada da sua contraparte brasileira, corresponde a um grande graben parcialmente invertido (Bassot 1988, Trompette 1994), constituindo assim uma estrutura de função similar à do Aulacógeno do Paramirim.

\section{Panorama cinemático do orógeno}

No mapa da Figura 8 e nas seções da Figura 9 estão representadas as grandes estruturas do orógeno e respectivas indicações do sentido de transporte tectônico. Nota-se que, à primeira vista, o quadro geral de movimentos associados com a deformação principal

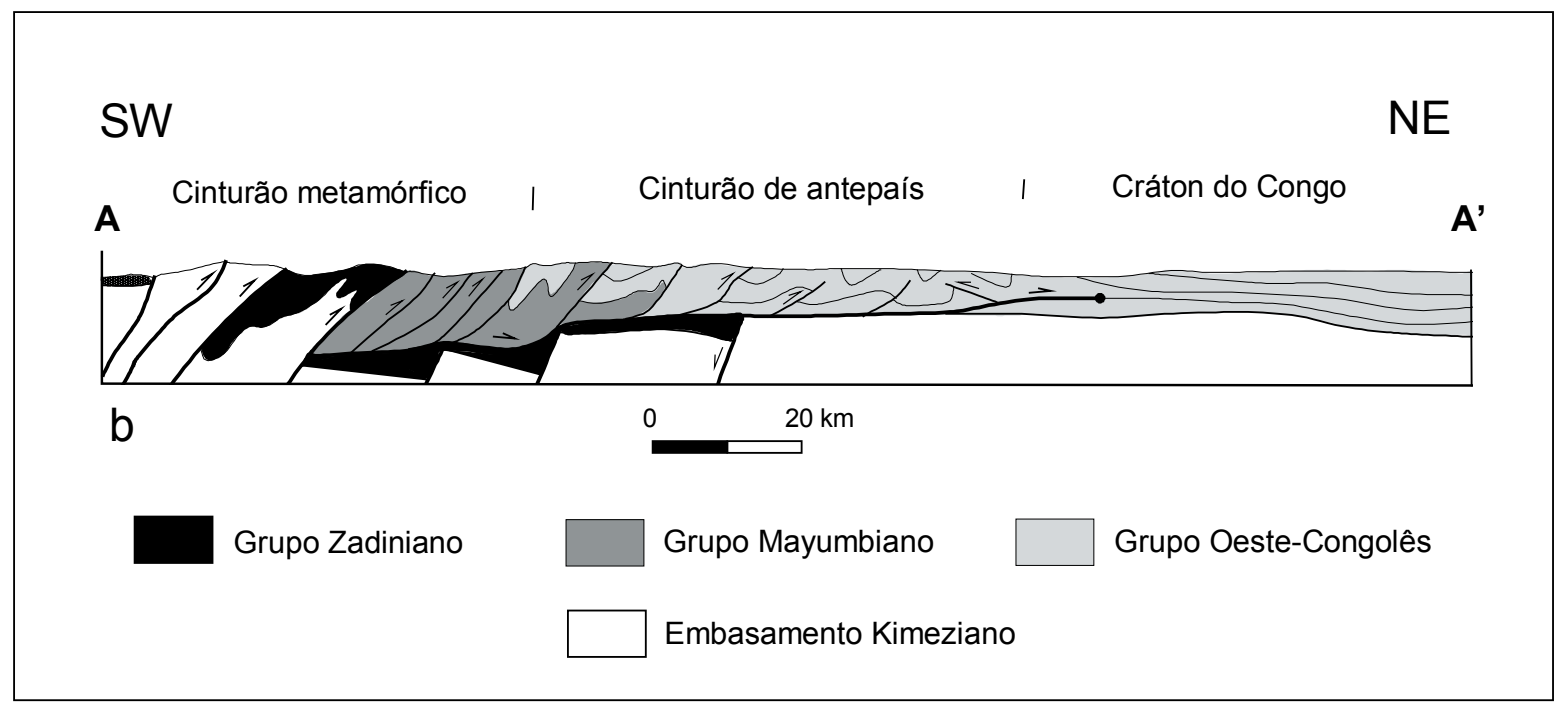

Figura 7. Seção geológica esquemática através da Faixa Oeste-Congolesa, confeccionada com base em Maurin (1993). Adaptado de Alkmim et al. (2006). Para localização, vide mapa da Figura 6. 


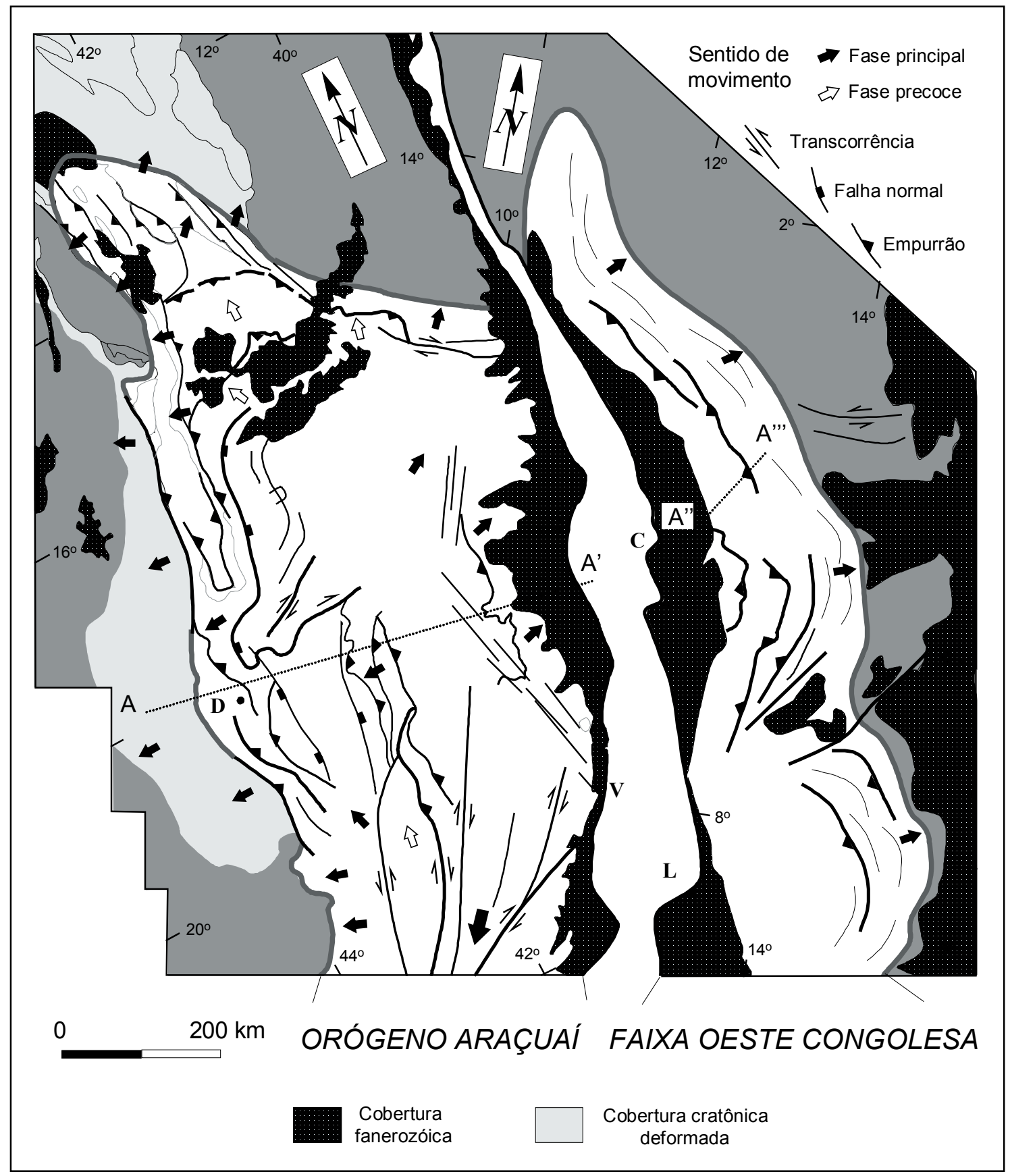

Figura 8. Mapa cinemático simplificado do Orógeno Araçuai-Congo Ocidental. Modificado de Alkmim et al. (2006).

sin-metamórfica é relativamente simples e centrífugo da zona orogênica para os crátons. Adicionalmente, verificam-se os enigmáticos movimentos da fase de deformação mais antiga dirigidos para norte, bem como a zona de escape lateral do núcleo cristalino e as estruturas distensionais, dentre elas, a da Chapada Acauã.

\section{EVOLUÇÃO TECTÔNICA}

Tendo por base os dados que, em grande parte, são discutidos neste e demais artigos do presente volume, a evolução tectônica do Orógeno Araçuaí-Congo Ocidental pode ser contada através de um modelo em cinco estágios principais, que são: i) da bacia precursora Macaúbas; ii) da convergência inicial; iii) colisional; iv) do escape lateral da porção sul; e v) do colapso gravitacional (Alkmim et al. 2006). Precederam este modelo, as proposições de Pedrosa-Soares et al. (1992), Trompette et al. (1992) e Maurin (1993).

\section{A bacia precursora Macaúbas}

No seu franco desenvolvimento, por volta de $660 \mathrm{Ma}$ (idade recentemente determinada para o 


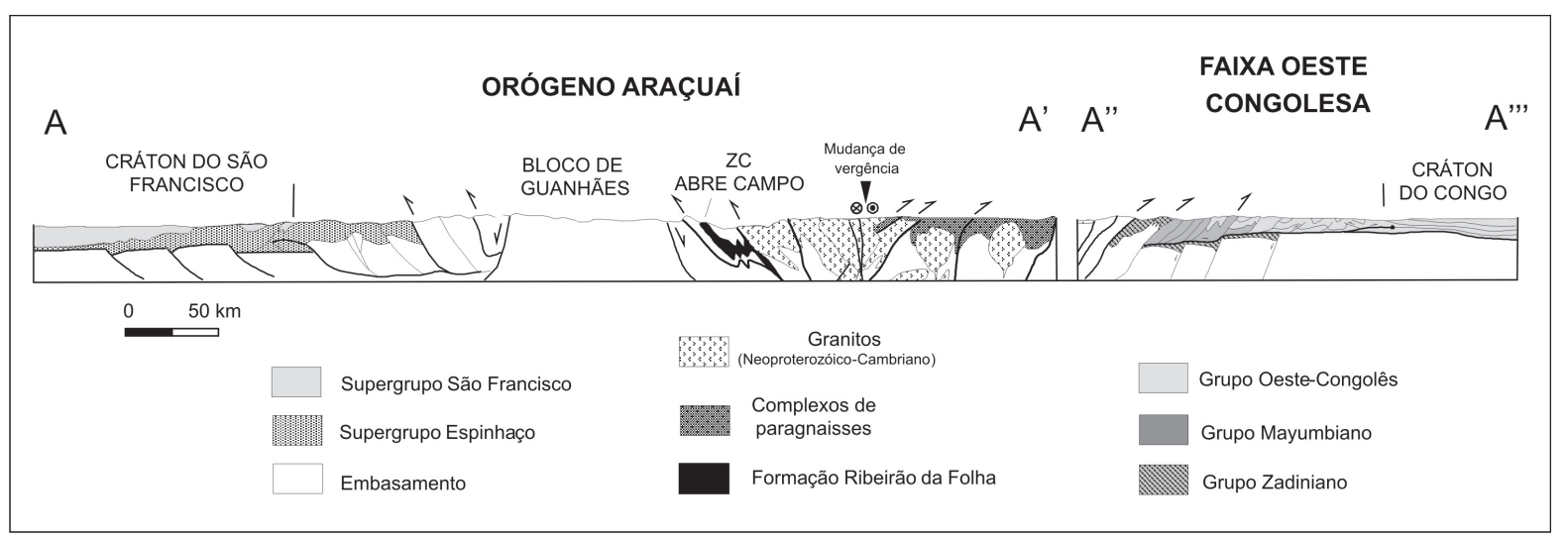

Figura 9. Seção geológica esquemática através de todo o Orógeno Araçuai-Congo Ocidental. Notar que, nesta visão, o orógeno apresenta a anatomia comum a diversos edifícios colisionais. Adaptado de Alkmim et al. (2006). Para localização, vide mapa da Figura 8.

ofiolito de Ribeirão da Folha; Queiroga et al. 2007), a bacia Macaúbas (Fig. 10), precursora do orógeno, deveria corresponder a algo como um grande golfo, parcialmente assoalhado por crosta oceânica (PedrosaSoares et al. 2001, 2007). Formada em uma fase de rifteamento que teve lugar no Paleocontinente São Francisco-Congo, em torno de $880 \mathrm{Ma}$ (Silva et al. 2007), a bacia Macaúbas evoluiria neste estágio para duas margens passivas, conectadas pelo que viria ser a ponte cratônica Bahia-Gabão (Porada 1989). As margens passivas hospedariam todas as unidades hoje encontradas nas faixas Araçuaí e Oeste-Congolesa e, muito provavelmente, uma grande espessura adicional de sedimentos não preservados (Fig. 10). Neste panorama, chama a atenção a longevidade da bacia Macaúbas que abarcaria um intervalo de existência de $c$ a. $220 \mathrm{Ma}$, tendo em vista o seu desenvolvimento como rifte continental por volta de 880 Ma e a produção de rochas magmáticas oceânicas em torno de $660 \mathrm{Ma}$. Tal fato poderia resultar de baixas taxas de expansão lateral no golfo Macaúbas, o que lhe conferiria um caráter estagnado e seria explicável uma vez que a bacia estaria quase totalmente circundada por massas continentais. Embora desconhecida, a quantidade de litosfera oceânica gerada nesta bacia deve ter sido significativa, ainda que restrita pelas dimensões do golfo, a ponto de participar, quando de sua subducção, na geração de magmas para o arco magmático.

As margens passivas da bacia precursora estariam ainda conectadas a pelo menos quatro riftes interiores (Fig. 1 e 10). No domínio São Francisco encontram-se os aulacógenos de Pirapora (Alkmim \& Cruz 2005) e Paramirim (Schobbenhaus 1996, Danderfer 2000, Cruz \& Alkmim 2006); no domínio Congo, tem-se o Aulacógeno Sangha ou Bacia de Comba (Trompette 1994, Alvarez \& Maurin 1991), além de uma estrutura de mesma natureza na terminação norte da Faixa Oeste-Congolesa (Bassot 1988). Estas estruturas desempenharam um importante papel, tanto na abertura quando no fechamento da Bacia Macaúbas. Elas foram responsáveis pela dissipação de tensões e acomodação de deformações no interior das zonas cratônicas.
Nas ilustrações das margens passivas da bacia Macaúbas, os seus substratos são dotados de altos externos (Fig. 10). O da margem oeste representaria o futuro Bloco de Guanhães que deixa de existir mais a norte, sendo substituído por um grande baixo. $\mathrm{O}$ alto externo da margem leste corresponderia ao substrato da porção interna do orógeno. Este alto será, nas etapas posteriores a esta, o sítio de instalação de um arco magmático e se converterá no seu núcleo cristalino.

\section{A convergência inicial}

Dada a configuração da bacia Macaúbas levá-la ao fechamento implica em invocar um mecanismo motriz que teria a subducção como conseqüência e não como causa, face à impossibilidade mecânica em fazer descer ao manto, por ação das forças gravitacional e de arrasto astenosférico, seu segmento oceânico fortemente atracado à crosta continental (Fig. 11). Postula-se, então, que o fechamento da bacia Macaúbas tenha sido induzido à distância, em conseqüência de colisão envolvendo a península São Francisco e a placa Paraná ou Rio de La Plata, por volta de $630 \mathrm{Ma}$ (Seer et al. 2001, Valeriano et al. 2004). Iniciar-se-ia, desta forma, a convergência das margens opostas da bacia Macaúbas, em uma operação que lembra o funcionamento de um quebra-nozes (Alkmim et al. 2006). Ou seja, a península São Francisco rotacionaria no sentido anti-horário, contra o continente Congo, levando a bacia Macaúbas a uma compressão generalizada e ao consumo de sua litosfera oceânica (Fig. 11). Por volta de 630 Ma já se tinha produção de tonalitos do arco magmático cálcioalcalino, relacionado a subducção (Pedrosa-Soares et al. 2001, Silva et al. 2005).

Duas questões relativas a este modelo devem ser aqui tratadas. A primeira delas se refere à localização do fulcro ou pólo de rotação durante a operação de fechamento do quebra-nozes. Encontram-se resposta para esta questão ao se considerar o que ocorrera na etapa de abertura da bacia. Como mencionado, a sua expansão foi viabilizada por significativa distensão no domínio cratônico, acomodada nos riftes interiores de Pirapora, Paramirim, Sangha e do extremo norte da 


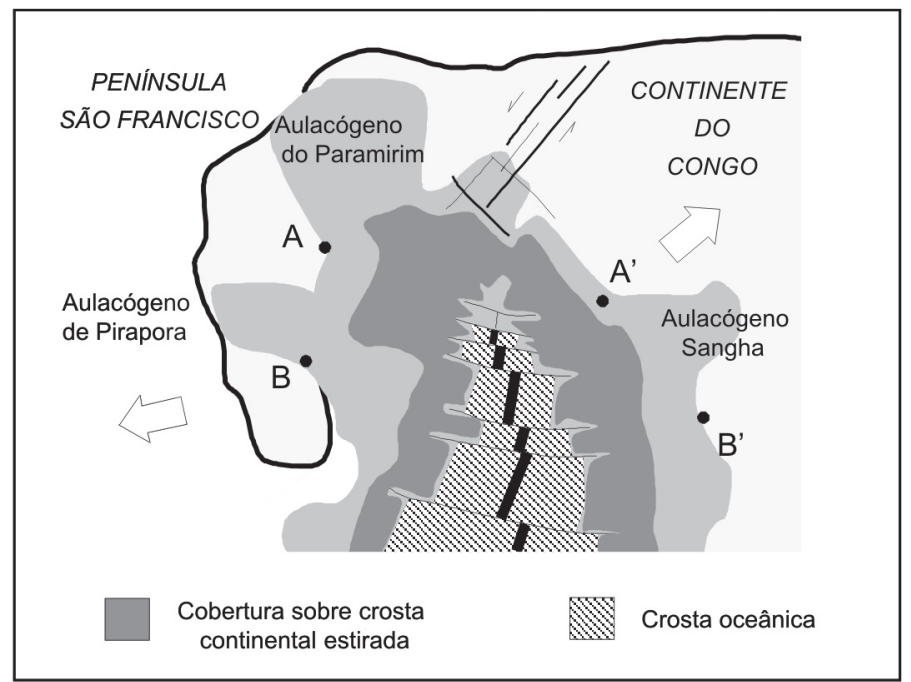

a

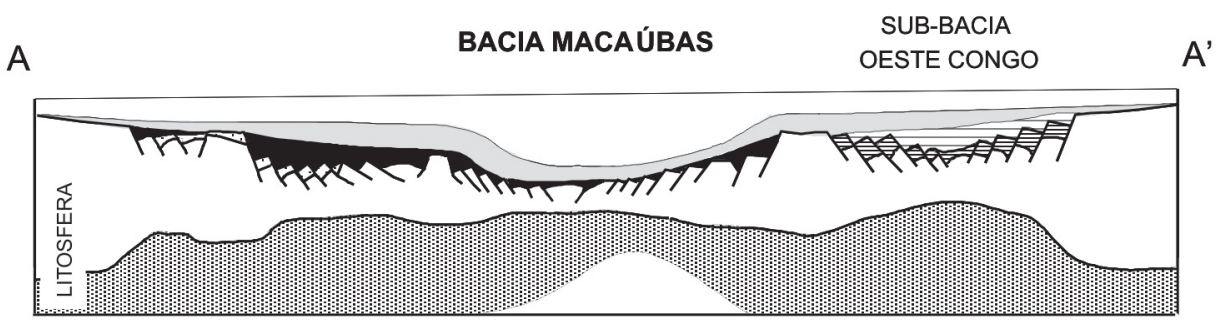

b

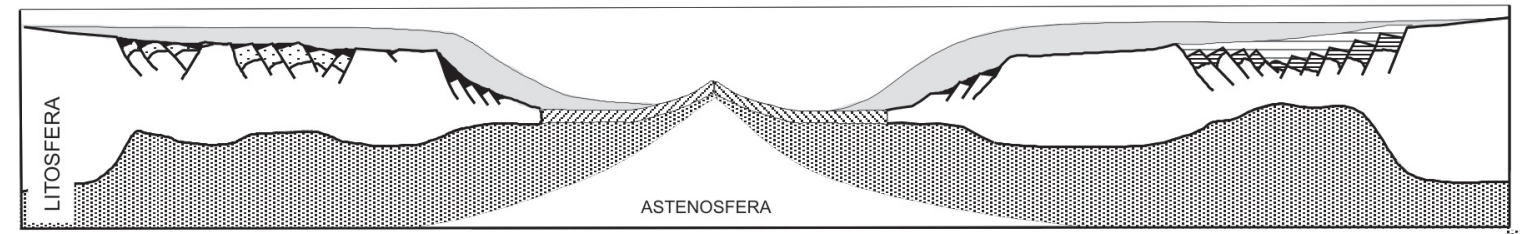

C

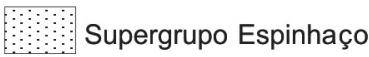

Grupos Macaúbas e Oeste-Congolês

Figura 10. Características da Bacia Macaúbas, precursora do orógeno, por volta de 700 Ma. a) Elementos da Bacia Macaúbas e seu cenário tectônico, vistos em mapa. b) Seção através do setor ensiálico (norte). c) Seção através do setor oceânico (sul).

Faixa Oeste-Congolesa. Assim, durante o fechamento, o mesmo se verificaria, ou seja, não haveria um só pólo fixo, mas vários e móveis, situados nos mencionados aulacógenos, os quais, nesta etapa, foram levados à inversão em variados graus. De fato, como se pode deduzir dos estudos realizados por Danderfer (2000) e Cruz (2004), o Aulacógeno do Paramirim exibe magnitudes de inversão decrescentes no sentido norte, chegando mesmo a preservar a geometria original do rifte no seu segmento setentrional.

A outra questão a ser tratada é a da produção de magma a partir da subducção do segmento oceânico relativamente limitado da bacia Macaúbas (Fig. 11). Neste problema as seguintes variáveis estão envolvidas: a) a idade da litosfera oceânica a ser consumida; b) as suas dimensões; c) a profundidade da astenosfera sob a placa superior, que marca a zona de inicio de produção de magma; d) o ângulo de subducção. No que tange a primeira variável, como mencionado anteriormente, o assoalho oceânico da bacia estagnada Macaúbas deveria possuir idade muito superior a $10 \mathrm{Ma}$, valor acima do qual a litosfera oceânica adquire empuxo negativo no manto e pode ser subductada. As demais variáveis podem ser analisadas conjuntamente. Admitindose uma espessura de $90 \mathrm{~km}$ para a profundidade da astenosfera na placa superior e um ângulo de subducção de $45^{\circ}$, uma distância mínima de cerca de $140 \mathrm{~km}$ seria requerida para que o segmento oceânico em subducção atingisse a zona de produção de magma no manto. Considerando-se uma taxa de produção de litosfera oceânica da ordem de $0,3 \mathrm{~cm} /$ ano - muito baixa, mas consistente com a natureza estagnada da 


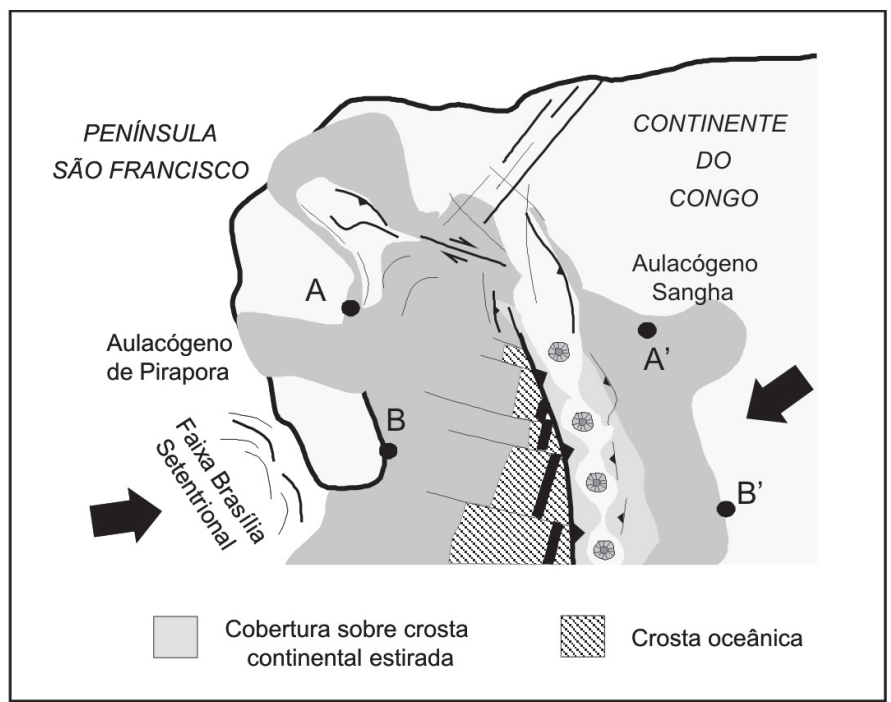

a

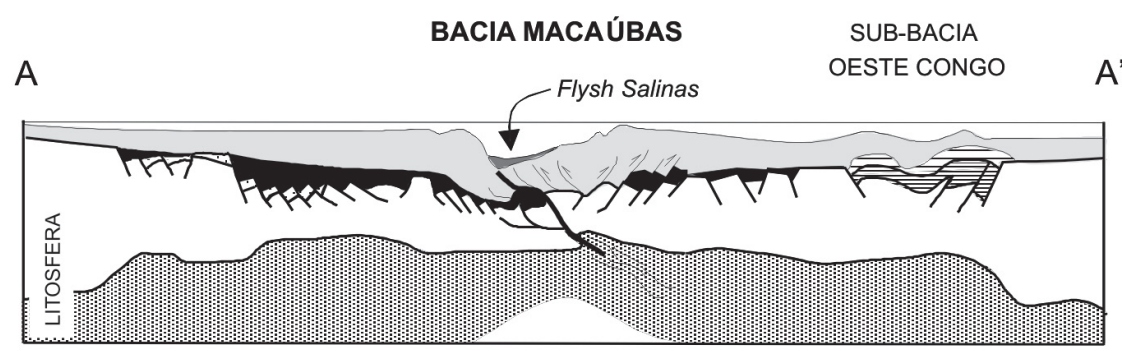

b

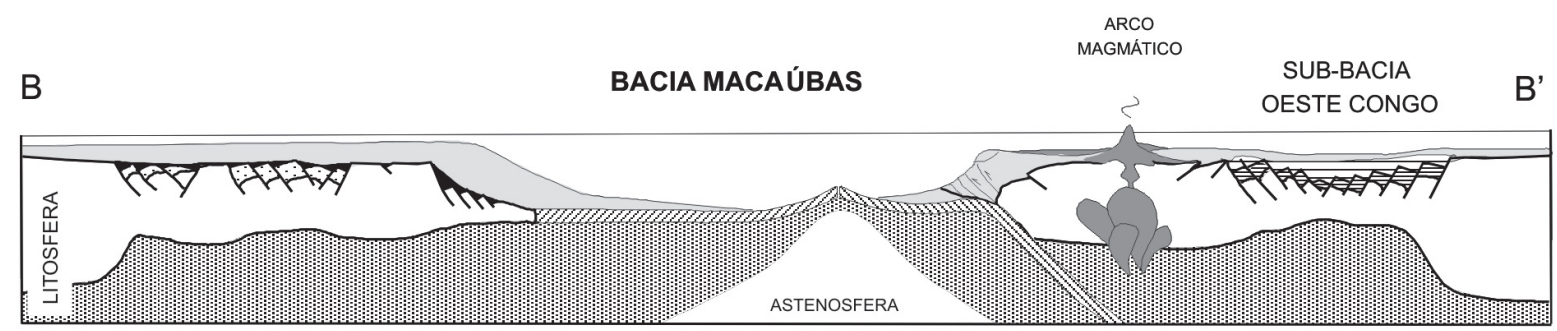

C Supergrupo Espinhaço $\$ Grupos Macaúbas e Oeste-Congolês

Grupos Zadiniano e Mayumbiano

Figura 11. Ilustração da fase de convergência inicial das margens da Bacia Macaúbas, por volta de 600Ma. a) Inicio da operação da tectônica do quebra-nozes, com o consumo forçado do assoalho da porção oceânica da bacia precursora, visto em mapa. b) Interação inicial das margens do setor ensiálico da bacia precursora, inicio da sedimentação sin-orogência (flysch) da Formação Salinas e inversão tectônica margem passiva leste.

c) Subdução do assoalho do setor oceânico da bacia precursora e instalação do arco magmático na margem leste, agora convertida em placa superior.

bacia Macaúbas - poder-se-ia produzir, em $150 \mathrm{Ma}$, um segmento oceânico de $500 \mathrm{~km}$ de extensão lateral, dimensão, portanto, mais que suficiente para, quando subductado, atingir a astenosfera e participar da geração de magmas. Há ainda que se considerar que a margem oeste da bacia Macaúbas, mesmo que dotada de um alto externo, deveria possuir uma espessura bem inferior aos $90 \mathrm{~km}$ empregados na estimativa (Fig. 11). Outro fator que facilitaria a produção de magma seria um ângulo de subducção superior a $45^{\circ}$, provável neste caso, em função da natureza forçada da subducção e da avançada idade média presumida para o assoalho oceânico da bacia Macaúbas.

Em torno de $600 \mathrm{Ma}$, um arco magmático de tamanho significativo já teria se implantado na margem leste da bacia, a este tempo convertida em margem ativa (Fig. 11c). A zona de subducção ativa no segmento sul da bacia seria representada no setor ensiálico, a norte, por uma frente de empurrões que envolveria os sedimentos da margem passiva distal e a sedim 
entação profunda do depocentro norte (Fig. 11b). Naquela porção da bacia, os sedimentos Salinas começariam a se acumular em grandes leques turbidíticos. Estes seriam alimentados por material advindo do arco, a sul, e da margem leste, em processo de soerguimento flexural, causado pela sobrecarga da margem oposta em aproximação (Fig. 11b).

\section{A etapa colisional}

Iniciando-se pelo norte e avançando progressivamente para sul, a colisão das margens opostas da bacia promoveria a propagação de frentes de empurrão para as zonas cratônicas, bem como o soerguimento da cadeia montanhosa (Fig. 12a), no intervalo compreendido entre 580 e $560 \mathrm{Ma}$ (Pedrosa-Soares et al. 2001, 2007).

Neste estágio seriam gerados os granitos G2 que são do tipo $\mathrm{S}$, ou seja, representam fusão parcial de protolitos sedimentares aluminosos (Pedrosa-Soares et al. 2007). O enorme volume destes granitos se explicaria pelo fato de terem sido produzidos a partir da fusão parcial de espessas pilhas de rochas metassedimentares a exemplo do que teria sido o golfo Macaúbas.

Um fenômeno ainda não totalmente esclarecido é o fato da fase mais antiga de deformação registrada no Orógeno Araçuaí estar associada com transporte tectônico dirigido para norte, ou seja, paralelamente à direção do orógeno. Talvez isto reflita um efeito precoce causado, na parte sudoeste do orógeno, pela rotação da extremidade meridional da península São Francisco contra o continente Congo.

\section{O escape lateral da porção sul do núcleo cristalino}

Como mencionado na seção anterior, a porção sul do compartimento central do orógeno é secionada por, pelo menos, quatro grandes zonas transcorrentes dextrais, que se formaram em estágio posterior à propagação das frentes de empurrão em direção aos crátons, provavelmente no intervalo entre 560 e 535 Ma (Alkmim et al. 2006). A movimentação dextral ao longo destas zonas implica em escape de material em direção a sul, o que pode ter se dado em decorrência da máxima aproximação entre o extremo sul da península São Francisco e a margem do continente do Congo,

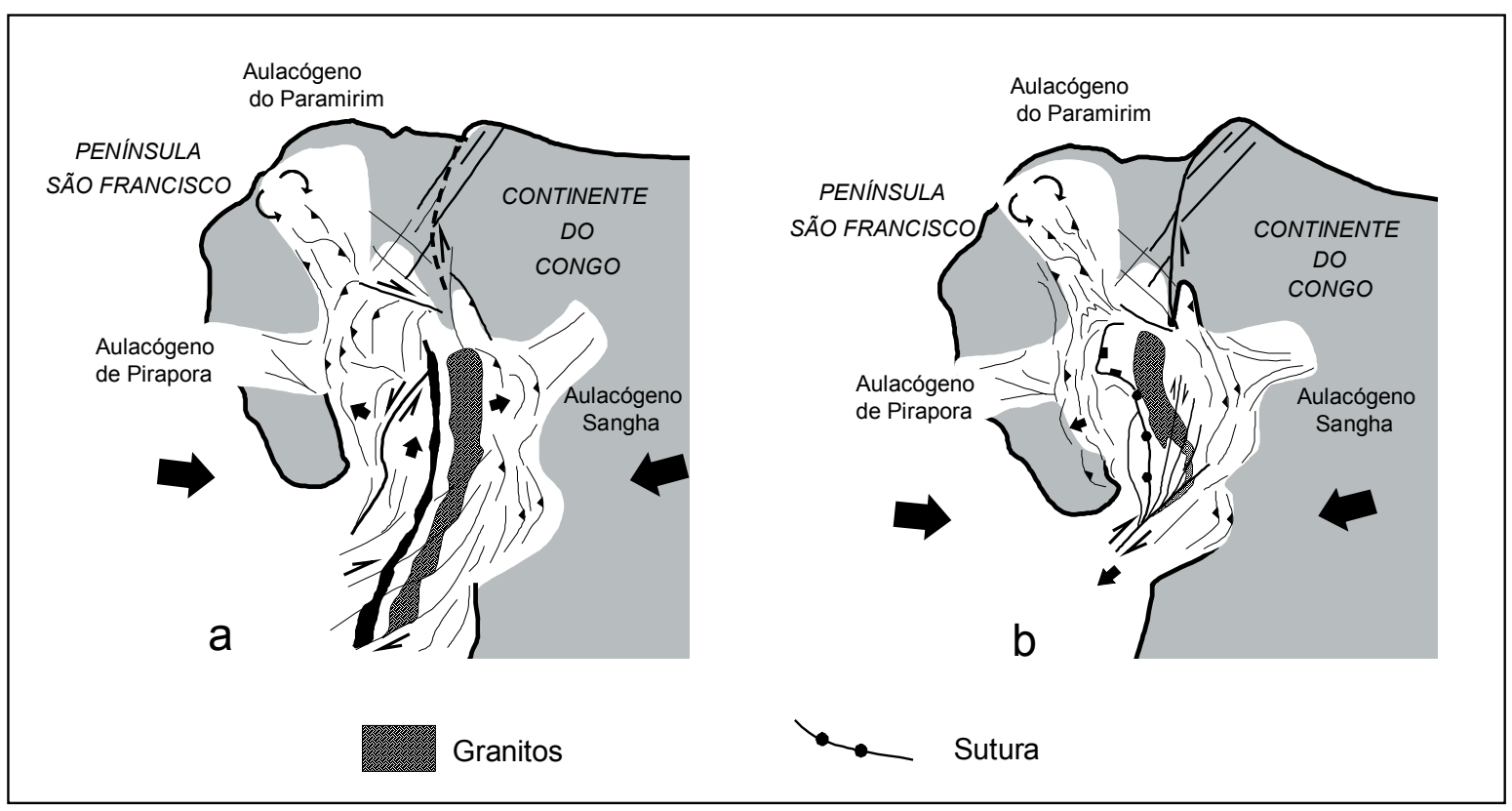

Figura 12. Cartoon ilustrativo dos estágios (a) colisional, por volta de $560 \mathrm{Ma}$, e (b) de colapso gravitacional, após escape lateral da porção sul do orógeno, por volta de 500 Ma. Adaptado de Alkmim et al. (2006).

aluminosas (hoje, em parte representadas pelas extensas unidades xistosas e complexos paragnáissicos), em decorrência do espessamento crustal causado pelas frentes de empurrão envolvendo o embasamento e o arco magmático. É fato que muitas bacias marinhas interiores (inland-sea basins) mesozóico-cenozóicas são preenchidas por enormes pilhas de sedimentos areno-pelíticos, depositadas sobre crosta adelgaçada, segundo a trajetória de fechamento do quebra-nozes (Fig. 12b).

\section{O colapso gravitacional}

Orógenos, nos quais a litosfera atinge altas espessuras, traduzidas por grandes elevações e alto potencial gravitacional, podem entrar em regime 
distensional sob ação da força peso (van Bemmelen 1954, Dewey 1988, England \& Houseman 1989, Malavieille 1993). A sobrecarga na crosta aquecida e, portanto, de baixa resistência leva ao fluxo lateral da sua porção basal e abatimento das porções superiores, acomodado por sistemas de zonas de cisalhamento normais. De acordo com este mecanismo teriam se desenvolvido a Zona de Cisalhamento Chapada Acauã e demais estruturas distensionais observadas principalmente nas porções central e norte do orógeno. Nesta fase, que teria lugar entre 520 e $490 \mathrm{Ma}$, seriam geradas as suítes graníticas G4 e G5, produtos de fusão crustal e mantélica por descompressão adiabática (Pedrosa-Soares \& Wiedemann-Leonardos 2000).

\section{COMENTÁRIO FINAL}

A investigação geológica realizada na Faixa Araçuaí e zonas adjacentes a leste e sul, desde a sua definição, há trinta anos, levou à sua comparação com feições homólogas do continente africano e possibilitou a caracterização do Orógeno AraçuaíCongo Ocidental. Muito há que fazer, porém, para uma melhor caracterização tanto de unidades envolvidas, quanto de peças do seu arcabouço e, desta forma, propiciar o completo entendimento do seu processo genético.

Neste sentido, vale mencionar que a região correspondente ao Orógeno Araçuaí constitui, por várias razões, um excepcional laboratório natural. Dentre estas razões, as principais são a natureza e qualidade das suas exposições de rochas e estruturas. Em virtude do soerguimento diferencial experimentado no período Cretáceo, o Orógeno Araçuaí encontra-se de tal forma exposto que, tanto no sentido de sul para norte, quanto de leste para oeste, viaja-se ao longo de seções completas da crosta inferior à crosta superior. Assim, a continuidade do seu estudo deverá oferecer às geociências não só soluções para os vários enigmas propostos pela geologia deste singular constituinte do Gondwana Ocidental, mas também para a elucidação de várias questões referentes à anatomia e gênese das cadeias de montanhas de um modo geral.

\section{REFERÊNCIAS}

Alkmim F. 2004. O que faz de um cráton um cráton ? O Cráton do São Francisco e as revelações Almeidianas ao delimita-lo. In: Mantesso-Neto et al. (eds) Geologia do Continente SulAmericano. Evolução da obra de Fernando Flávio Marques de Almeida. Becca, pp.: 17-35.

Alkmim F.F. \& Cruz S.C.P. 2005. Crátogenos, aulacógenos, orógenos e sua interação: O caso do Cráton do São Francisco-Congo e sistemas brasilianos/ pan-africanos adjacentes. In: SBG, Simp. sobre o Cráton do São Francisco, 3, Anais, p.185-187.

Alkmim F.F., Chemale Jr. F., Endo I. 1996. A deformação das coberturas proterozóicas do Cráton do São Francisco e o seu significado tectônico. Rev. Escola de Minas, 49:22-38.

Alkmim F.F., Marshak S., Pedrosa-Soares A.C., Peres G.G., Cruz S Whittington A. 2006. Kinematic evolution of the Araçuaí-West Congo orogen in Brazil and Africa: Nutcracker tectonics during the Neoproterozoic assembly of Gondwana. Precambrian Res.,
149: 43-64.

Almeida F.F.M. 1977. O Cráton do São Francisco. Rev. Bras. Geoc., 7: 285-295.

Almeida F.F.M. \& Hasui Y. 1984. O Précambriano do Brasil. Edgard Blücher, $378 \mathrm{p}$.

Almeida F.F.M., Hasui Y., Brito Neves B.B., Fuck R.A. 1981. Brazilian Structural Provinces: an introduction. Earth Sci. Rev., 17: 1-29.

Almeida F.F.M., Hasui Y., Rodrigues E.P., Yamamoto J.K. 1978. A faixa de dobramentos Araçuaí na região do Rio Pardo. In: SBG, Congr. Bras. Geol., 30, Anais, v.1, p. 270-283.

Barbosa J.S.F. \& Sabaté P. 2004. Archean and Paleoproterozoic crust of the São Francisco craton, Bahia, Brazil: geodynamic features. Precambrian Res., 133: 1-27.

Bassot, J.-P. 1988. Apport de la téledetéction à la compréhension de la géologie di Gabon. Chronique de la Recherche Minière, 491: 25-34.

Brueckner H.K., Cunningham D., Alkmim F.F., Marshak S. 2000. Tectonic implications of Precambrian Sm-Nd dates from the southern São Francisco craton and adjacent Araçuaí and Ribeira belts, Brazil. Precambrian Res., 99: 255-269.

Cahen L., Snelling N.J., Delhal J., Vail J.R. 1984. The Geochronology of Africa. Clarendon Press, 512 pp.

Campos Neto M.C., Figueiredo M.C.H. 1995. The Rio Doce Orogeny, Southeastern Brazil. J. South Am. Earth Sci., 8: 143-162.

Costa, A.G. 1989. Evolução petrológica para uma sequência de rochas metamórficas regionais do tipo baixa pressão, Itinga, NE-MG. Rev. Bras. Geoc., 19: 440-448.

Cruz S.C. 2004 A interação tectônica entre o Aulacógeno do Paramirim e o Orógeno Araçuai. Tese de Doutorado, Departamento de Geologia, Universidade Federal de Ouro Preto, 214 p.

Cruz S.C.P. \& Alkmim F.F. 2006 The tectonic interaction between the Paramirim Aulacogen and the Araçuaí belt, São Francisco Craton Region, Eastern Brazil. Anais Acad. Bras. Ciên., 78: 151-174.

Cunningham W.D., Marshak S., Alkmim F.F. 1996. Structural style of basin inversion at mid-crustal levels: two transects in the internal zone of the Brasiliano Araçuaí Belt, Minas Gerais, Brazil. Precambrian Res., 77: 1-15.

Cunningham D., Alkmim F.F., Marshak S. 1998. A structural transect across the coastal mobile belt in the Brazilian Highlands (latitude $\left.20^{\circ} \mathrm{S}\right)$ : the roots of a Precambrian transpressional orogen. Precambrian Res., 92: 251-275.

D’Agrella-Filho M. S., Pacca I. I. G., Teixeira W., Onstott T. C., Renne P.R. 1990. Paleomagnetic evidence for the evolution of Meso-to Neo-Proterozoic glaciogenic rocks in Central-Eastern Brazil. Palaeogeography, Palaeoclimatology, Palaeoecology, 80: $255-265$

D’Agrella-Filho M. S., Pacca I. I. G., Trindade R. I. F., Teixeira W., Raposo M. I. B., Onstott T. C. 2004. Paleomagnetism and ${ }^{40} \mathrm{Ar}^{39} \mathrm{Ar}$ ages of mafic dykes from Salvador (Brazil): new constraints on the São Francisco Craton APW path between 1080 and 1010 Ma. Precambrian Res., 132: 55-77.

Dahlen F.A., Suppe B., Davis D. 1984. Mechanics of fold-and-thrust belts and aecretionary wedges, cohesive Coulomb theory. $J$. Geophys. Res., 89: 10087-10101.

Danderfer, A. 2000. Geologia Sedimentar e Evolução Tectônica do Espinhaço Setentrional, Estado da Bahia. Tese de Doutorado, Instituto de Geociências, Universidade de Brasília, 498 p.

Dewey J.F. 1988. Extensional collapse of orogens. Tectonics, 7:1123-1139

De Wit M., Jeffery M., Bergh H., Nicolaysen L. 1988. Geologic map of sectors of Gondwana. AAPG and University of Witwatersrand, Tulsa.

Dussin T.M., 2000. A tectônica extensional paleoproterozóica na borda sudeste do Cráton do São Francisco (SE, Brasil): Geoquímica e petrologia das meta-ígneas. Geonomos, 8: 63-68.

Dussin I.A. \& Dussin T.M., 1995. Supergrupo Espinhaço: Modelo de evolução geodinâmica. Geonomos, 3: 19-26.

Endo I. 1977. Regimes Tectônicos do Arqueano e Proterozóico no interior da placa SanFranciscana: Quadrilátero Ferrifero e áreas adjacentes, Minas Gerais. Tese de Doutorado, Instituto de Geociências, Universidade de São Paulo, São Paulo, 243 pp.

England P.C. \& Houseman G.A. 1989. Extension during continental 
convergence, with application to the Tibetan Plateau. J. Geophys. Res., 94:17561-17579

Feybesse J.L., Johan V., Triboulet C., Guerrot C., Mayaga-Mikolo F., Bouchot V., Eko N'dong J. 1998. The West central African belt: a model of 2.5-2.0 Ga accretion and two-phase orogenic evolution. Precambrian Res., 87: 161-216.

Fischel D.P., Pimentel M.M., Fuck R.A., Costa A.G., Rosière C.A., 1998. Geology and Sm-Nd isotopic data for the Mantiqueira and Juiz de Fora complexes (Coastal Mobile belt) in the Abre Campo region, Minas Gerais, Brazil. In: International Conference on Precambrian and Craton Tectonics, Abstracts, p.21-23

Gradim R.J., Alkmim F.F., Pedrosa-Soares A.C., Babinski M., Noce C.M. 2005. Xistos verdes do Alto Araçuaí, Minas Gerais: Vulcanismo básico do rifte Neoproterozóico Macaúbas. Rev. Bras. Geociên., 35: 59-69.

Grossi-Sad J.H., Lobato L.M., Pedrosa-Soares A.C., Soares Filho B.S., 1997. Projeto Espinhaço em CD-ROM (textos, mapas e anexos). COMIG, Belo Horizonte, 2693 pp.

Haralyi N.L.E. \& Hasui Y. 1982. The gravimetric information and Archean-Proterozoic structural framework of eastern Brazil. Rev. Bras. Geociên., 112: 160-166.

Hasui Y., Almeida F.F.M., Brito Neves B.B. 1978. As estruturas brasilianas. In: SBG, Congr. Bras. Geol., 30, Anais, v. 6, p. 2423-2437.

Ledru P. J., Johan V., Milési J.P., Tegycy M. 1994. Markers of the last stage of the Paleoproterozoic collision: Evidence for a 2 Ga continent involving circum-South Atlantic provinces. Precambrian Res., 69: 169-191.

Lerouge C., Cocherie A., Toteu S.F., Penaye J., Milési J.-P., Tchameni R., Nsifa E.N.C., Fanning M., Deloul, E. 2006. Shrimp U-Pb zircon age evidence for Paleoproterozoic sedimentation and 2.05 Ga syntectonic plutonism in the Nyong Group, South-Western Cameroon: consequences for the Eburnean-Transamazonian belt of NE Brazil and Central. Africa. J. Afr. Earth Sci., 44: $127-413$.

Lima S.A.A., Martins-Neto M.A., Pedrosa-Soares A.C., Cordani U.G., Nutman A. 2002. A Formação Salinas na área-tipo, NE de Minas Gerais: Uma proposta de revisão da estratigrafia da Faixa Araçuaí com base em evidências sedimentares, metamórficas e idades U-Pb SHRIMP. Rev. Bras. Geociên., 32: 491-500.

Macedo J. M. \& Marshak S. 1999. Controls on the geometry of foldthrust belt salients. Geol. Soc. Am. Bull., 111: 1808-1822.

Malavielle J. 1993. Late orogenic extension in mountain belts: insights from the Basin and Range and the late Paleozoic Variscan Belt. Tectonics, 12: 1115-1130

Marshak S., Alkmim F.F., Whittington A., Pedrosa-Soares A.C. 2006. Extensional collapse in the Neoproterozoic Araçuaí orogen, eastern Brazil: A setting for reactivation of asymmetric crenulation cleavage. J. Structural Geol., 28: 129-147.

Mascarenhas, J.P., Pedreira, A., Gil, C.A., Neves, J.P., Oliveira, J.E., Silva-Filho, M.A. \& Marinho, M.M. 1979. Geologia da região centro-oriental da Bahia. Salvador, DNPM, Série Geologia 11, Seção Geologia Básica 8, 125 p.

Matos R.M.D. 1999. History of the northeast Brazilian rift system: kinematic implications for the break-up between Brazil and Africa. In: N.R. Cameron, R.H. Bate, V.S. Clure (Eds.) The oil and gas habitats of South Atlantic. Geological Society, London, Special Publication, 153, 55-73.

Maurin J.-C. 1993. La chaîne panafricaine ouest-congolienne: corrélation avec le domain est-brésilien et hypothese géodynamique. Bulletin de la Société Géologique de France, 164: 51-60.

Noce C.M., Macambira M.B., Pedrosa-Soares A.C. 2000. Chronology of Neoproterozoic-Cambrian granitic magmatism in the Araçuai Belt, Eastern Brazil, based on single zircon evaporation dating. Rev. Bras. Geociên., 30: 25-29.

Noce C.M., Silva L.C., Pedrosa-Soares A.C., Alkmim F.F., Peres G.G. 2003. O embasamento da Faixa Araçuaí no Bloco Guanhães: dados geocronológicos e evolução. In: SBG-MG, Simp. Geol. MG, 12, Anais, p. 90.

Noce C. M, Pedrosa-Soares A. C., Piuzana D., Armstrong R., Laux J H ; Campos C., Medeiros S. R. 2004. Ages of sedimentation of the kinzigitic complex and of a late orogenic thermal episode in the Araçuaí orogen, Northern Espírito Santo state, Brazil:
Zircon and monazite U-Pb SHRIMP and ID-TIMS data. Rev. Bras. Geociên., 34: 587-592.

Noce, C.M., Pedrosa-Soares, A.C., Silva, L.C., Armstrong, R. \& Piuzana, D. 2007. Evolution of polyciclic basement complexes in the Araçuaí orogen, based on U-Pb SHRIMP data: Implications for Brazil-Africa links in Paleoproterozoic time. Precambrian Research (no prelo)

Noce, C.M., Pedrosa-Soares, A.C., Silva, L.C. \& Alkmim, F.F. 2007. O Embasamento Arqueano e Paleoproterozóico do Orógeno Araçuaí. Geonomos, 15 (este número).

Novais L.C.C., Teixeira L.B., Neves M.T., Rodarte J.B.M., Almeida J.C.H., Valeriano C.M. 2004. Novas ocorrências de diques de diabásio na faixa Colatina - ES: estruturas rúpteis associadas e implicações tectônicas para as bacias de Campos e do Espírito Santo. Boletim de Geociências da Petrobrás, 12: 191-194.

Paixão, M.M. \& Perrella, P. 2004. Mapeamento geológico da área do contato entre o Maciço Granítico Salto da Divisa e o Complexo Jequitinhonha, Nordeste de Minas Gerais. Belo Horizonte, IGCUFMG, Trabalho de Graduação.

Pedrosa-Soares A.C. 1995. Potencial Aurífero do Vale do Araçuai, MG: História da Exploração, Geologia e Controle TectonoMetamórfico. Tese de Doutorado, Instituto de Geociências, Universidade de Brasília, 125 pp.

Pedrosa-Soares, A.C. \& Oliveira, M.J.R. 1997. Geologia da Folha Salinas. In: J.H. Grossi-Sad, L.M. Lobato, A.C. Pedrosa-Soares \& B.S. Soares-Filho (eds), Projeto Espinhaço em CD-ROM. Belo Horizonte, CODEMIG, p. 419-542.

Pedrosa-Soares A.C., Noce C.M., Vidal Ph., Monteiro R.L.B.P., Leonardos O.H. 1992. Towards a new tectonic model for the Late Proterzoic Araçuaí (SE Brazil) - West Congolian (SW Africa) Belt. J. S. Am. Earth Sci., 6: 33-47.

Pedrosa-Soares, A.C., Leonardos, O.H., Ferreira, J.C. \& Reis, L.B. 1996. Duplo regime metamórfico na Faixa Araçuaí: Uma reinterpretação à luz de novos dados. In: Congresso Brasileiro de Geologia, 39, Salvador. SBG, Anais, v. 6, p. 5-8.

Pedrosa-Soares A.C., Vidal Ph., Leonardos O.H., Brito-Neves B.B. 1998. Neoproterozoic oceanic remnants in eastern Brazil: Further evidence and refutation of an exclusively ensialic evolution for the Araçuaí-West Congo Orogen. Geology, 26: 519-522.

Pedrosa-Soares A.C. \& Wiedemann-Leonardos C.M. 2000. Evolution of the Araçuaí belt and its connection to the Ribeira Belt, Eastern Brazil. In: U.G. Cordani, E.J. Milani, A. Thomaz Filho, D.A. Campos (Eds.) Tectonic Evolution of South America. São Paulo, SBG, p. 265-285.

Pedrosa-Soares A.C., Noce C.M., Wiedemann C.M., Pinto C.P. 2001. The Araçuaí-West Congo orogen in Brazil: An overview of a confined orogen formed during Gondwanland assembly. Precambrian Res., 110: 307-323.

Pedrosa-Soares, A. C., Castañeda, C., Queiroga, G., Gradim, C., Belém, J., Roncato, J., Novo, T., Dias, P., Gradim, D., Medeiros, S., Jacobhson, T., Babinski, M. \& Vieira, V. 2006. Magmatismo e Tectônica do Orógeno Araçuaí no Extremo Leste de Minas Gerais e Norte do Espírito Santo. Geonomos, 14 (2): 97-111.

Pedrosa-Soares, A.C., Noce, C.M., Alkmim, F.F., Silva, L.C., Babinski, M., Cordani, U., Castañeda, C. 2007. Orógeno Araçuaí: síntese do conhecimento 30 anos após Almeida 1977. Geonomos, 15 (este número).

Pedrosa-Soares, A.C., Alkmim, F.F., Tack, L., Noce, C.M., Babinski, M., Silva, L.C., Martins-Neto, M.A. 2008. Similarities and differences between the Brazilian and African counterparts of the Neoproterozoic Araçuaí-West-Congo orogen. Geological Society, London, Special Publications, 294 (no prelo).

Peres G.G., Alkmim F.F., Jordt-Evangelista H. 2004. The southern Araçuaí belt and the Dom Silvério Group: Geologic architecture and tectonic significance. An. Acad. Bras. Ciên., 76: 771-790.

Porada H. 1989. Pan-African rifting and orogenesis in southern to equatorial Africa and Eastern Brazil. Precambrian Res., 44: 103-136.

Queiroga, G.N., Pedrosa-Soares, A.C., Noce, C.M., Alkmim, F.F., Pimentel, M.M., Dantas, E., Martins, M., Castañeda, C., Suita, M.T.F. \& Prichard, H. 2007. Age of the Ribeirão da Folha ophiolite, Araçuaí Orogen: The U-Pb Zircon (la-icpms) dating of a plagiogranite. Geonomos, 15 (este número).

Radambrasil 1983. Folhas Rio de Janeiro e Vitória, vol. 34, 544 p. 
Renne P. R., Onstott T. C., D’agrella Filho M. S., Pacca I. I. G., Teixeira W. $1990 .{ }^{40} \mathrm{Ar} /{ }^{39} \mathrm{Ar}$ dating of 1.0-1.1 Ga magnetizations from the São Francisco and Kalahari Cratons: Tectonic implications for Pan-African and Brasiliano mobile belts. Earth Plan. Sci. Letters, 101: 349-366.

Rolim V.K. \& Alkmim F.F. 2004. Geometria 3D de falhas de empurrão e dobras associadas como expressões da morfologia do descolamento basal: Resultados de uma simulação computacional. Rev. Bras. Geociên., 34: 295-302.

Ribeiro-Althoff A.M., Cheilletz A., Guiliani G., Féraud G., Barbosa-Camacho G., Zimmermann J.L. 1997. ${ }^{40} \mathrm{Ar} /{ }^{39} \mathrm{Ar}$ and $\mathrm{K}-\mathrm{Ar}$ geochronological evidence for two periods $(\sim 2 \mathrm{Ga}$ and 650-500Ma) of emerald formation in Brazil. Int. Geol. Rev., 39: 924-937.

Sampaio, A.R., Martins, A.M., Loureiro, H.C., Arcanjo, J.B., MoraesFilho, J.C., Souza, J.D., Pereira, L.H., Couto, P.A., Santos, R.A., Melo, R.C., Bento, R.V. \& Borges, V.P. 2004. Projeto Extremo Sul da Bahia: Geologia e Recursos Minerais. Salvador, Série Arquivos Abertos da Companhia Bahiana de Pesquisa Mineral, 19, $52 \mathrm{p}$.

Santos R.F., Alkmim F.F., Pedrosa-Soares A.C. 2007. A Formação Salinas, Orógeno Araçuaí, MG: História deformacional e significado tectônico. Rev. Bras. Geoc. (submetido).

Schobbenhaus C. 1996. As tafrogeneses superpostas Espinhaço e Santo Onofre, Estado da Bahia: Revisão e novas propostas. Rev. Bras. Geociên., 26: 265-276.

Seer H.J., Brod J.A., Fuck R.A., Pimentel M.M., Boaventura G.R., Dardenne M.A. 2001. Grupo Araxá em sua área tipo: Um fragmento de crosta oceânica neoproterozóica na Faixa de Dobramentos Brasília. Rev. Bras. Geociên., 31: 396-924.

Silva L.C., Amstrong R, Noce C.M, Carneiro M., Pimentel M.M., Pedrosa-Soares A.C., Leite C.A, Vieira V.S., Silva M.A., Paes V.J.C., Cardoso Filho J.M. 2002. Reavaliação da evolução geológica em terrenos pré-cambrianos brasileiros com base em novos dados U-Pb SHRIMP, parte II: Orógeno Araçuaí, Cinturão Móvel Mineiro e Cráton São Francisco Meridional. Rev. Bras. Geociên., 32: 161-174.

Silva, L.C., McNaughton, N.J., Armstrong, R., Hartmann, L. \& Fletcher, I. 2005. The Neoproterozoic Mantiqueira Province and its African connections. Precambrian Research, 136: 203-240.
Silva, L.C., Pedrosa-Soares, A.C. \& Teixeira, L.R. 2007. Tonian rift-related, A-type continental plutonism in the Araçuaí orogen, Eastern Brazil: new evidences for the breakup stage of the São Francisco-Congo Paleocontinent. Gondwana Research (no prelo).

Tack L., Wingate MT.D., Liégeois J.-P., Fernandez-Alonso M., Deblond A. 2001. Early Neoproterozoic magmatism (1000-910 $\mathrm{Ma}$ ) of the Zadinian and Mayumbian Groups (Bas-Congo): onset of Rodinian rifting at the western edge of the Congo craton. Precambrian Res., 110: 277-306.

Trompette R. 1994. Geology of Western Gondwana (2000-500 Ma). Pan-African-Brasiliano aggregation of South America and Africa. A.A. Balkema, Rotterdam, $350 \mathrm{pp}$.

Trompette R., Uhlein A., Egydio-Silva M.E., Karmann I. 1992. The Brasiliano São Francisco craton revisited (central Brazil). J. S. Am. Earth Sci., 6: 49-57.

Uhlein A. 1991. Transição cráton-faixa dobrada: um exemplo do Cráton do São Francisco e da Faixa Araçuai (ciclo Brasiliano) no Estado de Minas Gerais. Tese de Doutorado, Instituto de Geociências, Universidade de São Paulo, 295 pp.

Uhlein A., Trompette R., Silva M.E. 1986. A estruturação tectônica do Supergrupo Espinhaço na região de Diamantina, MG. Rev. Bras. Geociên., 16: 212-216.

Uhlein A., Trompette R., Egydio-Silva M. 1998. Proterozoic rifting and closure, SE border of the São Francisco Craton, Brazil. J. S. Am. Earth Sci., 11: 191-203.

Uhlein A. 2004. Paleogeografia e inversão tectônica da Faixa Araçuai e do Corredor do Paramirim, região centro-leste do Brasil. Tese de Livre Docência, Instituto de Geociências, Universidade de São Paulo, 130 pp.

Valeriano, C.M., Machado, N., Simonetti, A., Valladares, C.S., Seer, H.J., Simões, L.S.A., 2004. U-Pb geochronology of the southern Brasília belt (SE-Brazil): Sedimentary Provenance, Neoproterozoic orogeny and assembly of West-Gondwana. Precambrian Res., 130 (1/4), 27-55.

Vieira, V.S. 2007. Significado do Grupo Rio Doce no Contexto do Orógeno Araçuaí. Belo Horizonte, IGC-UFMG, Tese de Doutorado.

van Bemmelen, R.W. 1954. Mountain building. Ed. Martinus Nijhoff, The Hague, 177 pp. 